
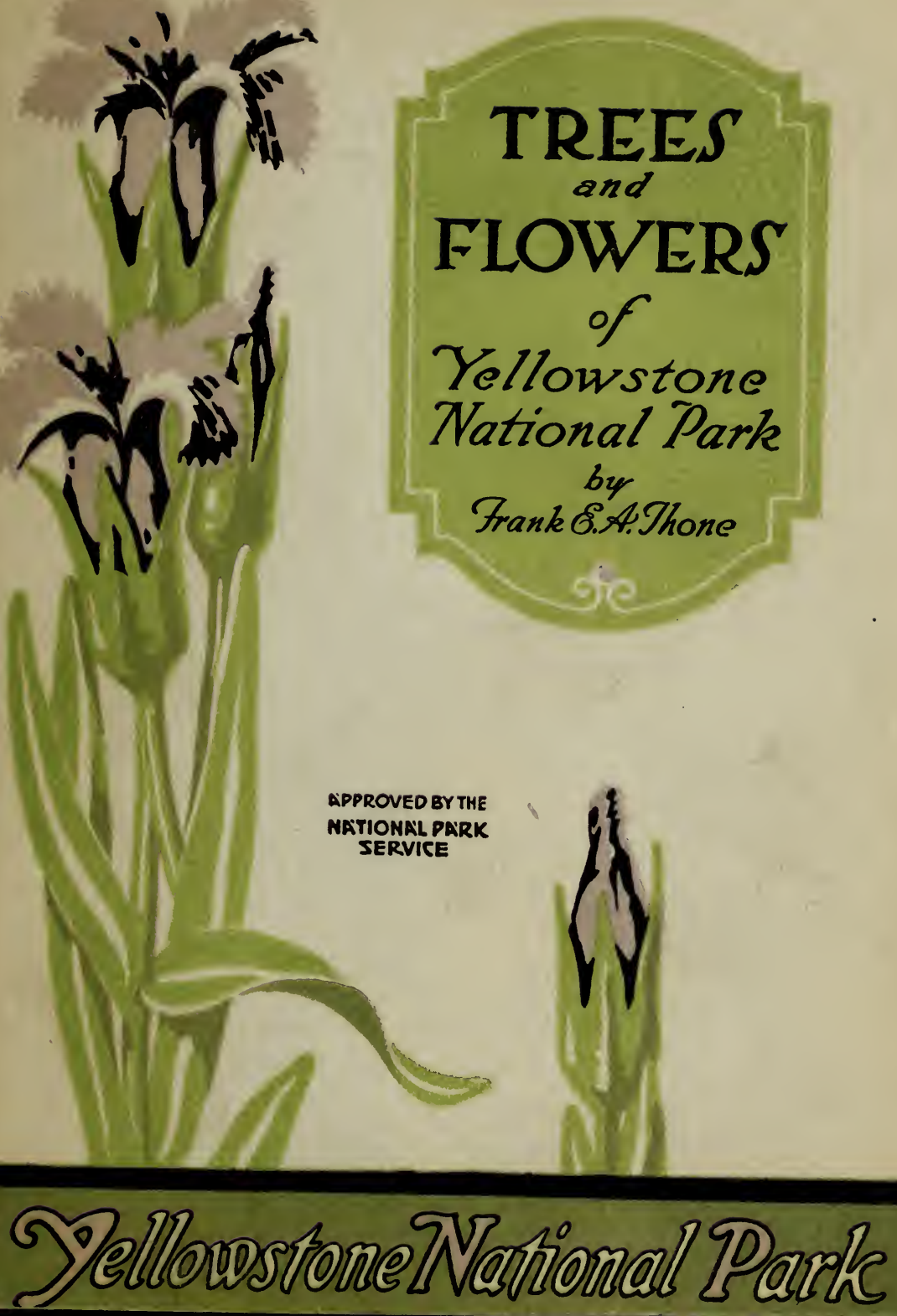
Digitized by the Internet Archive in 2013 



\title{
TREES AND FLOWERS of YELLOWSTONE NATIONAL PARK
}

\author{
By \\ Frank E. A. Thone, Ph. D. \\ Park Lecturer
}

\section{Approved by THE NATIONAL PARK SERVIGE}

\author{
Sketches by \\ MARGARET A. THONE, M. A. \\ Photographs by \\ J. E. HAYNES, B. A. \\ Park Photographer \\ J. E. Haynes, Publisher \\ Saint Paul
}


Text and Drawings Copyrighted 1923 by FRANK E. A.THONE

Photographs

Copyrighted 1923 by

J. E. HAYNES

All Rights Reserved 
22703 (O) J. E. HAYNES, ST. PAUL

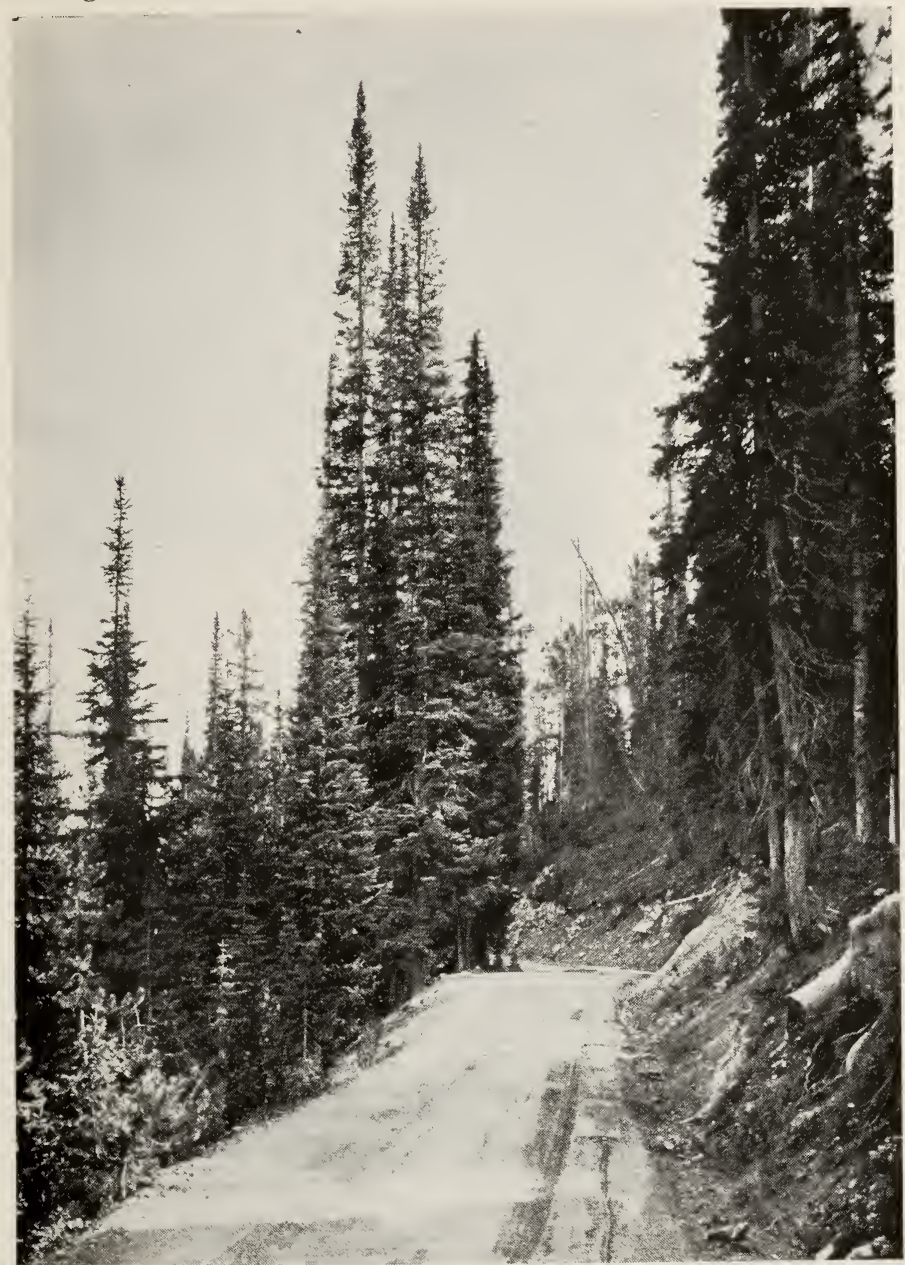

SPRUCE TREES ALONG CONTINENTAL DIVIDE ROAD

Donglas spruce and Englemann spruce are "climax" trees; they make up the most highly developed type of forest possible in this region. 


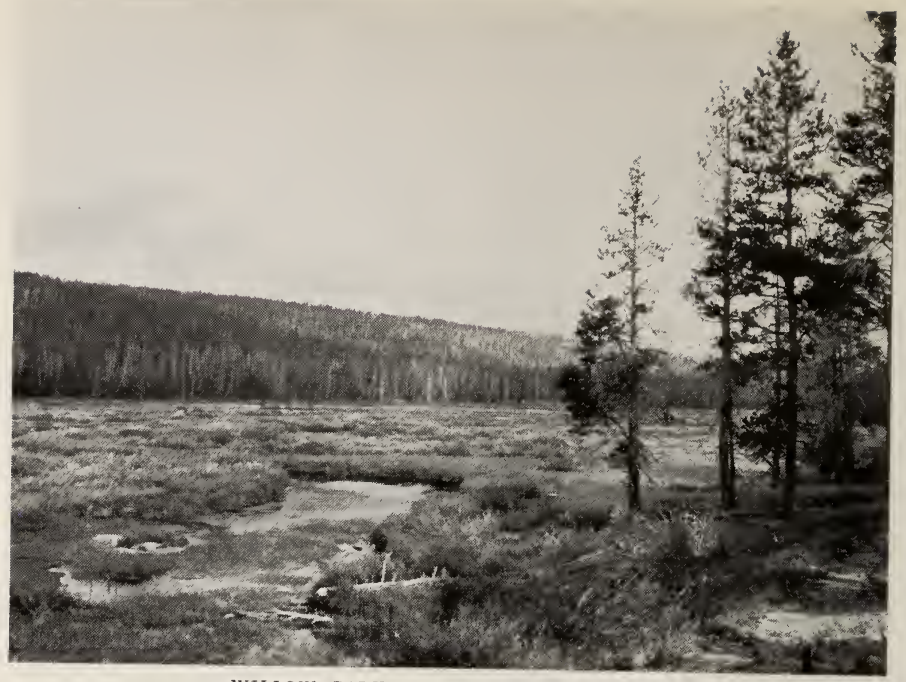

WILLOW PARK: AN OLI LAKE BOTTOM

When a lake dries up, the first woody plants are willows, alders, and sinilar bushes. The lodgepole pine on the shore is waiting its chance to invade when the land becomes dry enough.

22707 (C) J. E. HAYNES, ST. PAUL

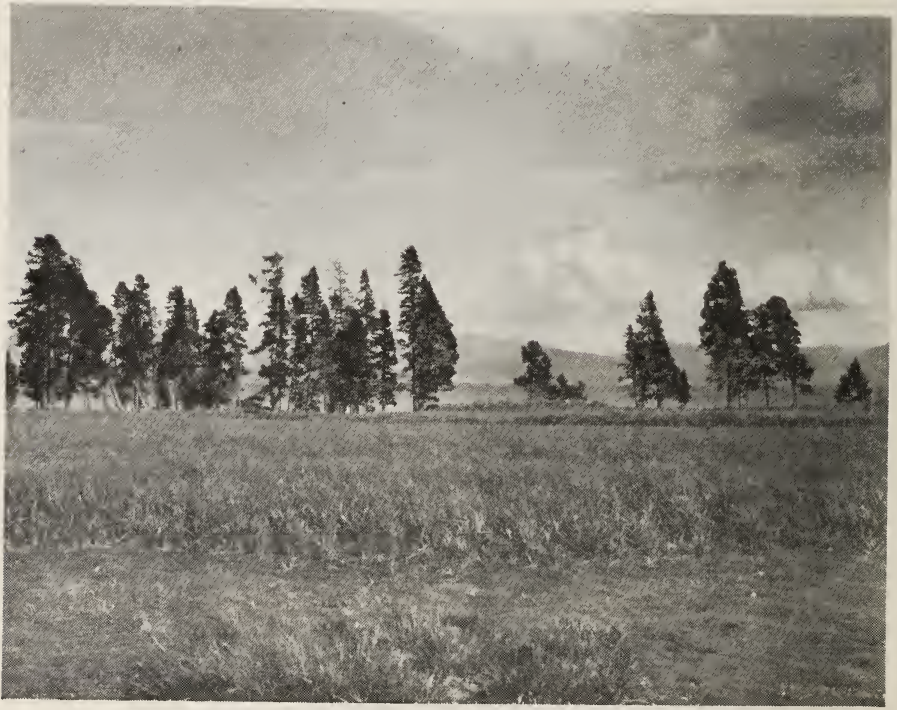

TRAPPED: REMNANT OF A SPRUCE FOREST

The meadow in the foreground remained too wet for the spread of the spruce. In the meantime the ridge on which the forest stood has been almost entirely eaten away by the waves of Yellowstone Lake behind it. 


\section{FOREWORD}

\section{On what has been left out.}

Most books begin with a preface explaining their contents, and sometimes even apologizing for them. To the present writer this seems an idle and unprofitable practice, for one can easily find out what is in the text by reading it, and a book that requires an apology had better be left unwritten. Sufficient explanation for the bringing forth of this small volume can be found in the pressing demand, hitherto unsatisfied, for a book in plain, non-technical English, on the trees and flowers of the Yellowstone National Park. It will be realized, of course, that where many readers are to be reasonably well satisfied, few or none can be satisfied with absolute completeness; certain shortcomings are thus recognized as unavoidable and therefore not to be apologized for. Time and space will be more profitably employed considering the reasons for omissions that seemed desirable or necessary.

It is obviously impossible to include in a small book a comprehensive treatment of all of the six or seven hundred species of flowering plants to be found in the Park. It is not even desirable, for many of them are either rare, or inconspicuous, or obscure and difficult of determination, and of interest only to professional botanists. Some common-enough forms, like the grasses and sedges, do not interest the average visitor much, and moreover are determinable only by experts. Others, finally, like the cattails, thistles and wild mustards, are so familiar as to need no aid in 
identification. A selection has therefore been made of about one hundred of the plants most frequently seen and inquired about by visitors to the Park.

In this book, technical terms and treatment have been avoided whenever possible. For the most part the genus is the smallest group considered, as the average visitor is not interested in fine distinctions among species; and even if he were he would get small comfort from the professional botanists, who are too often in hopeless disagreement among themselves. For those who are interested in more exact determinations, there is no substitute for the complete floras of Coulter and Nelson and of Rydberg, covering the whole Rocky Mountain region. Mention must also be made of "Rocky Mountain Flowers," by Clements and Clements, a work combining a high degree of scientific accuracy with adaptability for popular use, and illustrated with finely colored plates.

No artificial "key" has been included in this work, for it has been the writer's experience that these are rarely, if ever, used by the layman. The usual practice is to turn the leaves of the book until a picture is found that corresponds with the flower under examination.

The plants are grouped according to their growthform, as trees, shrubs and herbs, but beyond that they are left in approximately the same order in which their family affinities place them. This sets flowers of similar form and evolutionary history together, and has at least the virtue of being a natural arrangement.

Frank E. A. Thone. 


\section{CONTENTS}

Page

Flowers, poem ..................... 8

How the Plants Came to Yellowstone Park .......... 10

Trees .................................. 14

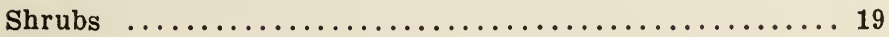

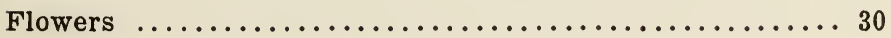

Game Laws for Wild Flowers ................65

Index to English Names.................. 67

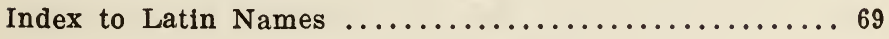




\section{FLOWERS}

When God had framed the firmament And poured the flowing seas,

In pity for the naked earth

He made the grass and trees.

With samite capes he robed the hills,

He tapestried the plain;

He planted oaks and cedar trees,

Plumed reeds and bearded grain.

Knowing our needs, all needful things

He stablished for our weal:

He gave us wood, He gave us food,

He gave us herbs that heal.

But for the Image of Himself

That mortal flesh embowers

He made His latest, choicest gift-

He gave the soul His flowers. 
He plucked the jewels from His crown And strewed them with His hands,

He smiled to watch them as they fell

On all the wide earth's lands.

There is no northern shore so bleak,

No mountain-top so bare,

There is no desert so accursed,

But God's gems blossom there.

And every unplowed acre bears

$A$ heaven with stars and suns,

And any weed may wear a robe

Richer than Solomon's.

The angels well might envy us

This great gift that is ours,

This still-renewing miracle,

The Sacrament of the Flowers. 


\section{HOW THE PLANTS CAME TO YELLOW. STONE PARK.}

People who come to Yellowstone Park to see the geysers and the canyons (and these are, of course, what most people come here to see) are taking a good deal for granted. Not more here than elsewhere, to be sure, for it is human nature to take for granted the most familiar and essential things-air and water, for example, or our families and friends. Things that we never lack we are seldom very acutely aware of.

Certainly this is true of the trees and wild flow. ers. We simply accept them as an inevitable part of the landscape, and give them no credit for their importance to our comfort and enjoyment. Yet if there were no trees in the Park, if there were no wild flowers and smaller plants, the place would be desert and ac. cursed; a waste of barren rock, like the Thingvalla, that dreary plain that guards the approach to the geysers of Iceland; and instead of the tens of thousands of visitors that throng the Park every year only an occasional hardy traveller or determined scientist would pass through the gates. The trees and flowers are not the most important things about the Yellowstone Park, but they are none the less an indispensable part of it.

If the vegetation of the Park is essential for the enjoyment and comfort of visitors in general, it is an exhaustless treasure and a continuous delight to all lovers of trees and flowers. All imaginable types of habitat and life conditions are present, and each offers its appropriate display of plant life. Forests of lodgepole pine dominate the rather thin, dry soil of the park plateau, yielding place to fir and spruce in the moister, richer ravines. Dry flats and hillsides are gray with sagebrush, sometimes verging abruptly on wet meadows rank with marsh-grasses and willow 
bushes. The Sahara-like aridity of the staring sands in the geyser basin is relieved by a few hardy little dwarfs. The crossing of the continental divide, which nine out of ten visitors imagine will be a place of rocky steepness, is marked by a little lake full of water-lilies! Contrasts extend even to temperature conditions: There are tiny plants, gay with bloom, under the edges of the mountain snowbanks; and a low form of plant life (one of the algae) waves its trailing filaments in the almost boiling water of the hot springs.

But the plants are more than a variegated and interesting setting and complement to the other wonders of the Park. They are not static, passive things, but actors in a most intense drama of their own, a silent play of struggle and success, tragedy and triumph, that to those who can read it aright is as absorbing as an epoch in the history of our own race.

The stage is broad, and the time of the acting is in keeping with the magnitude of the setting. The drama began at the end of the glacial epoch, fifty or a hundred thousand years ago. This region must then have presented a most desolate aspect. Where the ice had plowed, the sides of the hills and canyons were scraped to the bare bones of the rock. In the lower valleys lay the moraines, dumps of mud and boulders left by the glaciers as they melted; smooth, round hills now, but then scarred with a thousand gullies cut by the torrential rains, looking very much like the "bad lands" of Dakota. Even the lower mountains had heavy caps of snow throughout the year, and many of them still bore stubs of glaciers on their sides. Ice floated on the sullen lakes; the rivers were gorged with turbid, muddy water throughout the brief summers. The only signs of warmth were unhealthy ones: huge volumes of steam rising into the chilly air from the white blisters on the landscape that were the geyser and hot springs formations. 
Into such a "stern and rock-bound" land came the pioneers of the plant societies that followed the retreating ice. There was no comeliness about them, nor any stature; they were small, sober, patient plants, whose descendants now dwell on the tundras of the arctic regions. It is possible that they found a little plant life when they came; lichens and mosses at least, and perhaps a few of their own kin, relicts of the earlier world of plants that had fallen before the invasion of the ice. At first they found a foothold in sheltered crevices and on the sunny sides of the hills. Very gradually they extended and consolidated their holdings, seizing on the soil that slowly weathered from the bare rock and weaving it into their turf of roots, moving in wherever the lichens and mosses prepared a place for them. The rocky landscape lost much of its forbidding front, the erosion of the morainal hills was checked, and life became possible for other, less meager plants that followed from the south as the climate continued to modify.

As the summers became warmer they also became longer and drier. Less and less of the terrain was occupied with permanent snow and ice, and life became possible in constantly enlarging areas. The longer growing seasons also made new forms of life possible, and newcomers appeared in increasing numbers. Large bushes and even trees came in, and the development of the forests began. The country began to take on a modern aspect.

The drying-up process continued, and the hillsides at the lower altitudes began to be unable to support forests. The trees gave way before the incoming sagebrush, and retreated to the park plateau, except for certain drought-tolerating forms, like cedar and limber pine. The earliest comers, forced by the competition of the later arrivals still to keep to arctic conditions, retired to the mountain-tops, or even dis- 
appeared altogether. Some of the more adaptable of the newcomers followed on up the mountains and took up their abode there.

Even after all available room was taken up by the plants the drama continued, and it still goes on. No area where a plant can get a roothold is left bare, and as soon as conditions become unfavorable for one species, forcing it to give up the fight, its place is taken over by another that is adapted to the changed circumstances. If a lily pond dries up, the bottom is soon occupied with cattails and rushes, which are succeeded by sedges and grasses, and these by willows, and finally the forest comes in. If a dry, sagebrush-covered hillside develops a gully where a trickle of moisture persists, the sagebrush must yield to plants that can make more advantageous use of the water. First a few shrubs, then a thicket of aspen, and finally fir or spruce or pine. The aspen always pioneers, pushing up the slopes and out into the open, carrying the new conditions to some extent in its shade, and conquering new land for the trees that follow.

Thus the drama continues, year after year, century after century, the plants sometimes fiercely competing, sometimes accommodating each other, but always and unceasingly struggling against circumstance and exploiting to the limit the opportunities that the environment allows. What the last act will be is of course outside human prophecy or even conjecture. But in the meantime the student of nature, or the lay. man with a philosophical turn of mind, will find much fascinating food for thought in every meadow and on every mountain-side. 


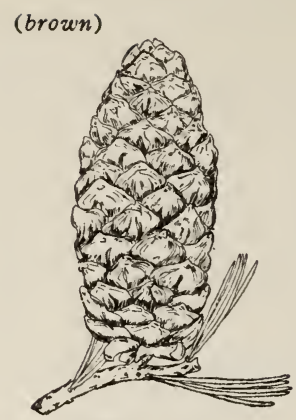

LIMBER PINE (brown)

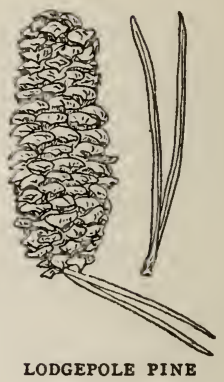

TREES.

Limber Pine (Pinus flexilis). The limber pine is the dominant tree below the level of the park plateau; it is especially abundant at Mammoth Hot Springs. It generally forms rather scattered stands, and in consequence is seldom a symmetrical tree. Its freely branching, bushy habit makes it bizarre and picturesque rather than beautiful. It belongs to the white pine group, and the needles are therefore borne in groups of five. The cones open and fall soon after ripening, so that the trees may be identified at a distance by the bunches of immature cones at the extreme ends of the branches.

Lodgepole Pine (Pinus Murrayana). The lodgepole pine is by far the most abundant tree species in the Park, making up nearly three-fourths of the whole tree population. It is almost always found at the level of the park plateau, where it forms very dense forests. The trees are usually straight and slender, and where the stand is dense bear their branches only near the top. It is a yellow pine, and the needles grow in clusters of two, or sometimes three. The cones are small, and hang on the branches for a long time. Normally they never open until a forest fire sweeps through the woods. This dependence on heat to open the cones works as an advantage to the tree, giving it a start over all other species after a forest fire. 


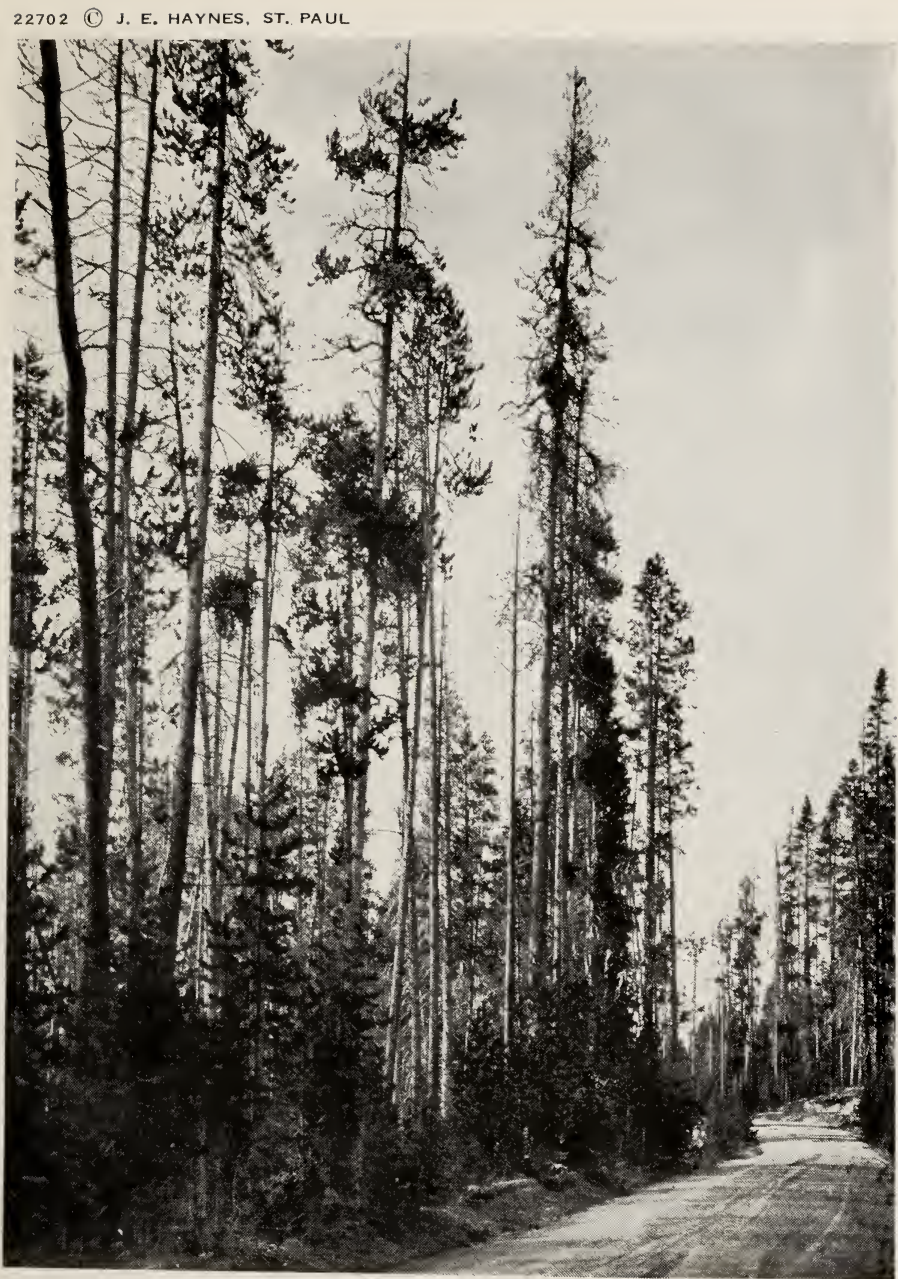

LODGEPOLE PINE DOMINATES THE PARK PLATEAU

Lodgepole pine is a pioneer tree, occupying burnt-over areas and thriv. ing on poor soils. Typically, the trees are close-set, slender, and "weedy." 


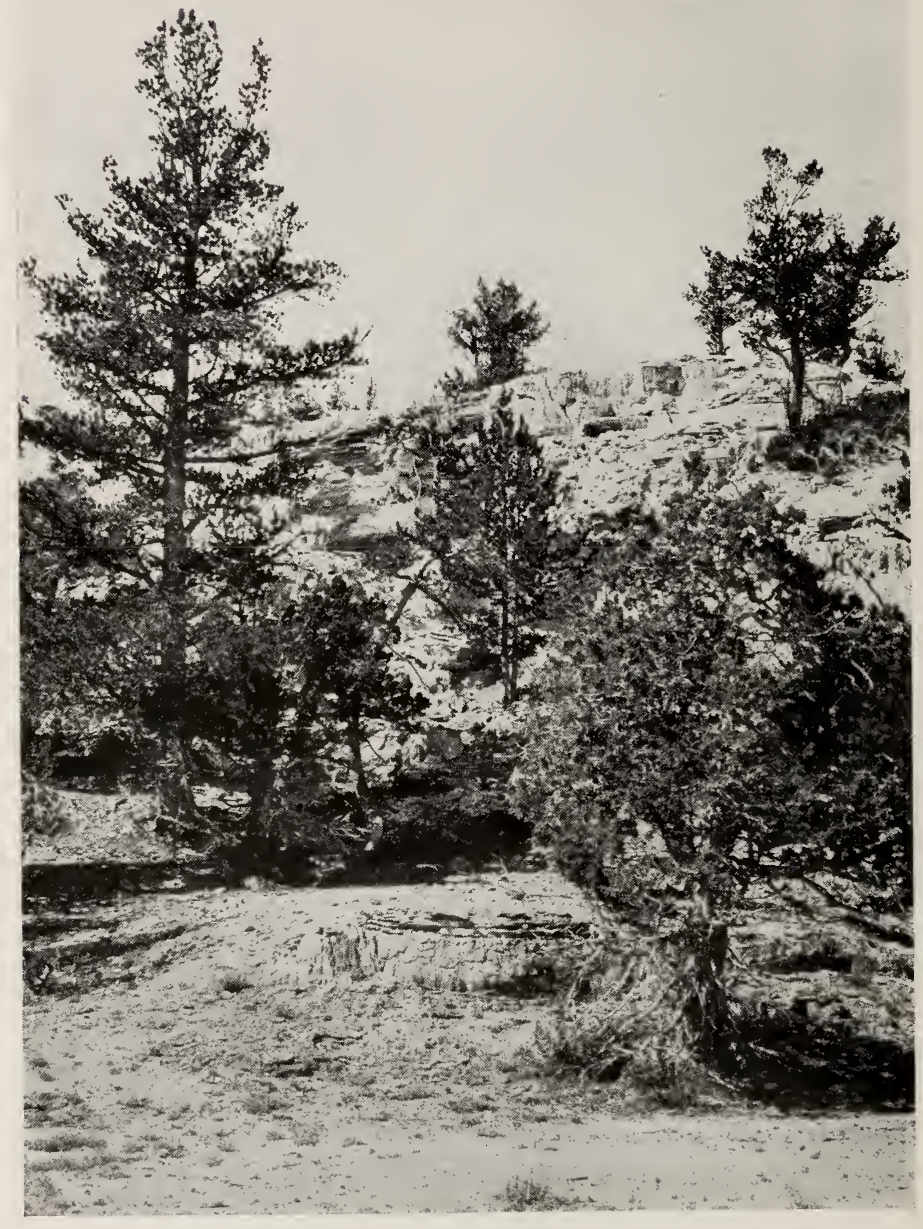

LIMBER PINE AND JUNIPER ON MAMMOTH TERRACES

Limber pine, and hoth bushy and tree junipers thrive in dry places at the lower altitudes. They are able to maintain a foothold even on the sterile soil of the hot springs formations. 


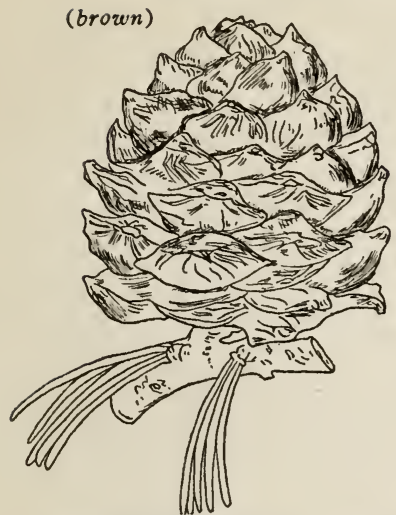

WHITEBARK PINE (brown)

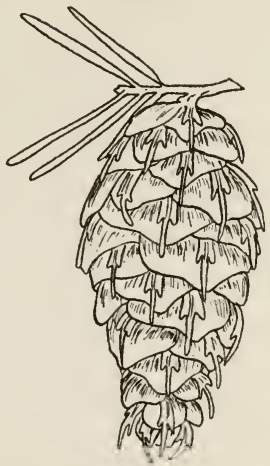

DOUGLAS FIR

Whitebark Pine (Pinus albicaulis). This is the third of the three species of pine found in the Yellowstone Park. It grows only on the higher mountains near the timber-line, and the only place in the Park where it can be found close to an automobile road is along Dunraven Pass and near the summit of Mount Washburn. The tree is a white pine, with its needles in bunches of five, but its most distinguishing mark is the smooth, silvery-gray bark that persists even on trunks and branches of considerable size. Like all trees near timberline, the whitebark pine never becomes large, and it is frequently crooked and deformed.

Douglas Fir (Pseudotsuga). Next to the lodgepole pine, the Douglas fir is the most abundant tree in the Park. It prefers moist canyons, hillsides, and forests where other trees have already developed shelter and shade. It is large, symmetrical tree, frequently reaching a diameter of three or four feet, with many branches. Like all firs and spruces, it bears its needles singly instead of in bunches. An unmistakable feature, found in no other species, is the three-pointed bract or appendage that projects over each scale of the cone. 

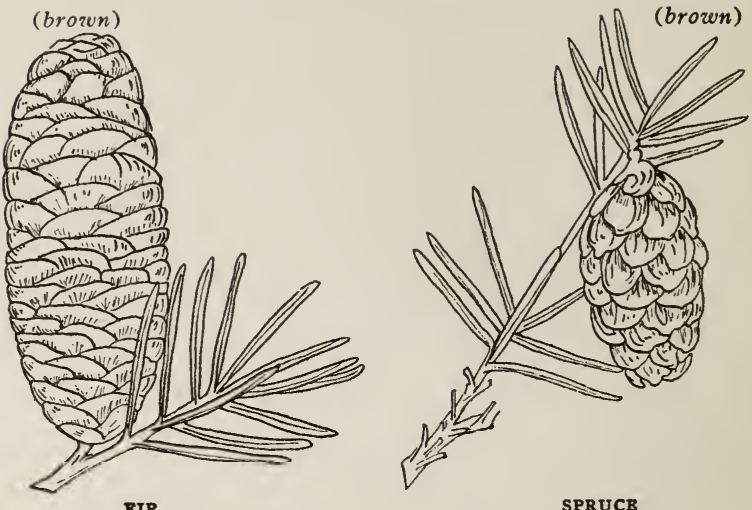

Fir (Abies). The true fir, known also as the balsam, is not very abundant in the Park, though it occurs in many widely separated localities. It is a fast-growing tree, reaching a large size, and developing a fine, symmetrical pyramidal form. The needles are somewhat flatter and softer than those of the Douglas fir or of the spruce, and are so arranged that they form a row on either side of the twig, instead of standing out on all sides of it. The scales of the cones are smoother than in the other evergreens, and are rounded instead of being pointed on the ends. The cones stand upright on the branches, instead of hanging down. The bark is sticky with a gummy balsam.

Spruce (Picea). Like the fir, the spruce occurs only occasionally, and then mixed with other timber. It becomes a tall tree, but tends to remain rather slender and spire-shaped, especially in the thick woods. Its needles are shorter, much stiffer and more prickly than those of the fir, and are arranged in spiral fashion on the twig, standing out on all sides. They have a tendency to fall off, leaving the twigs rough with their persistent bases. The cones are smaller than those of the Douglas fir or the balsam, and hang downward from the branches. 


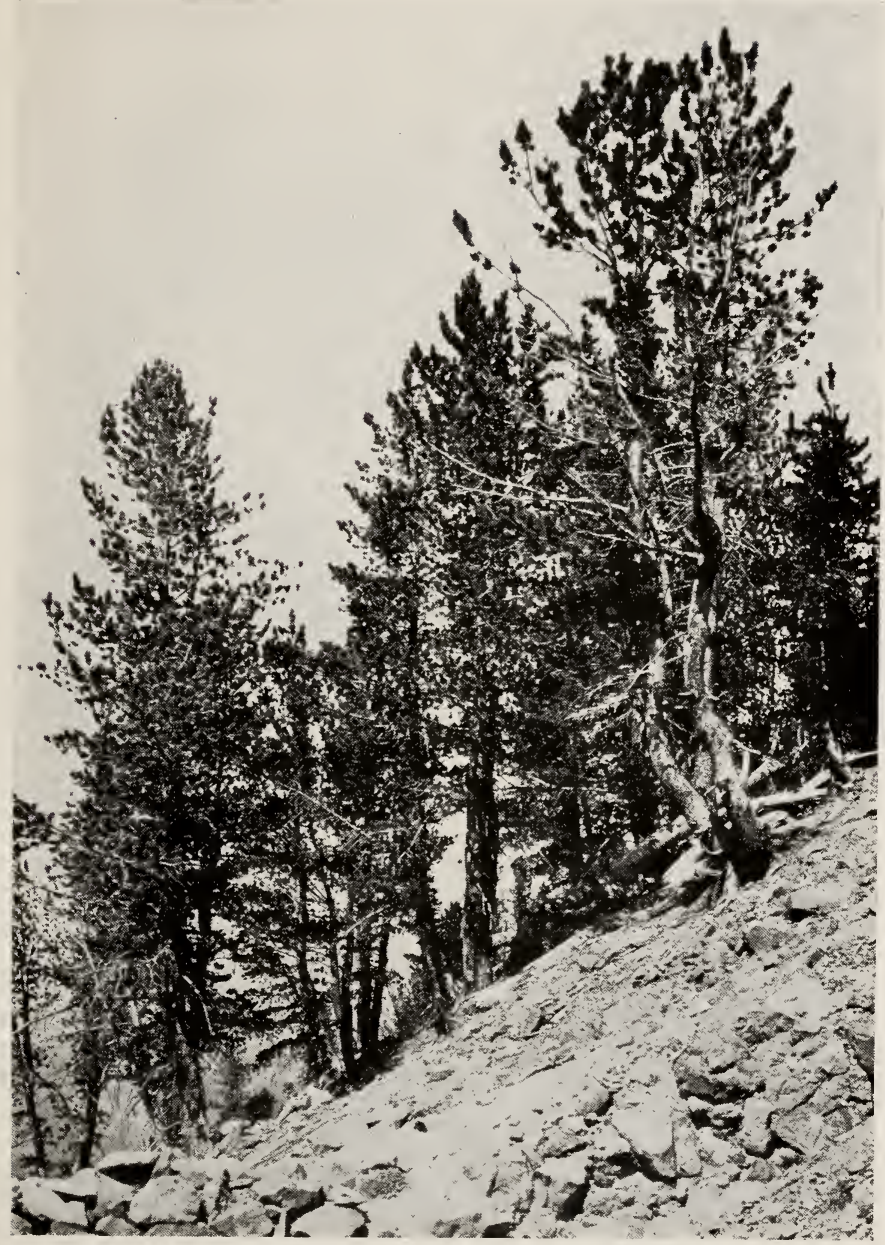

WHITEBARK PINE ON MOUNT WASIHBURN

The dominant pine at mountain-top altitudes is the whitebark. It climbs high above the limits of the lodgepole pine and Douglas spruce, and accompanies Englemann spruce to timberline. 


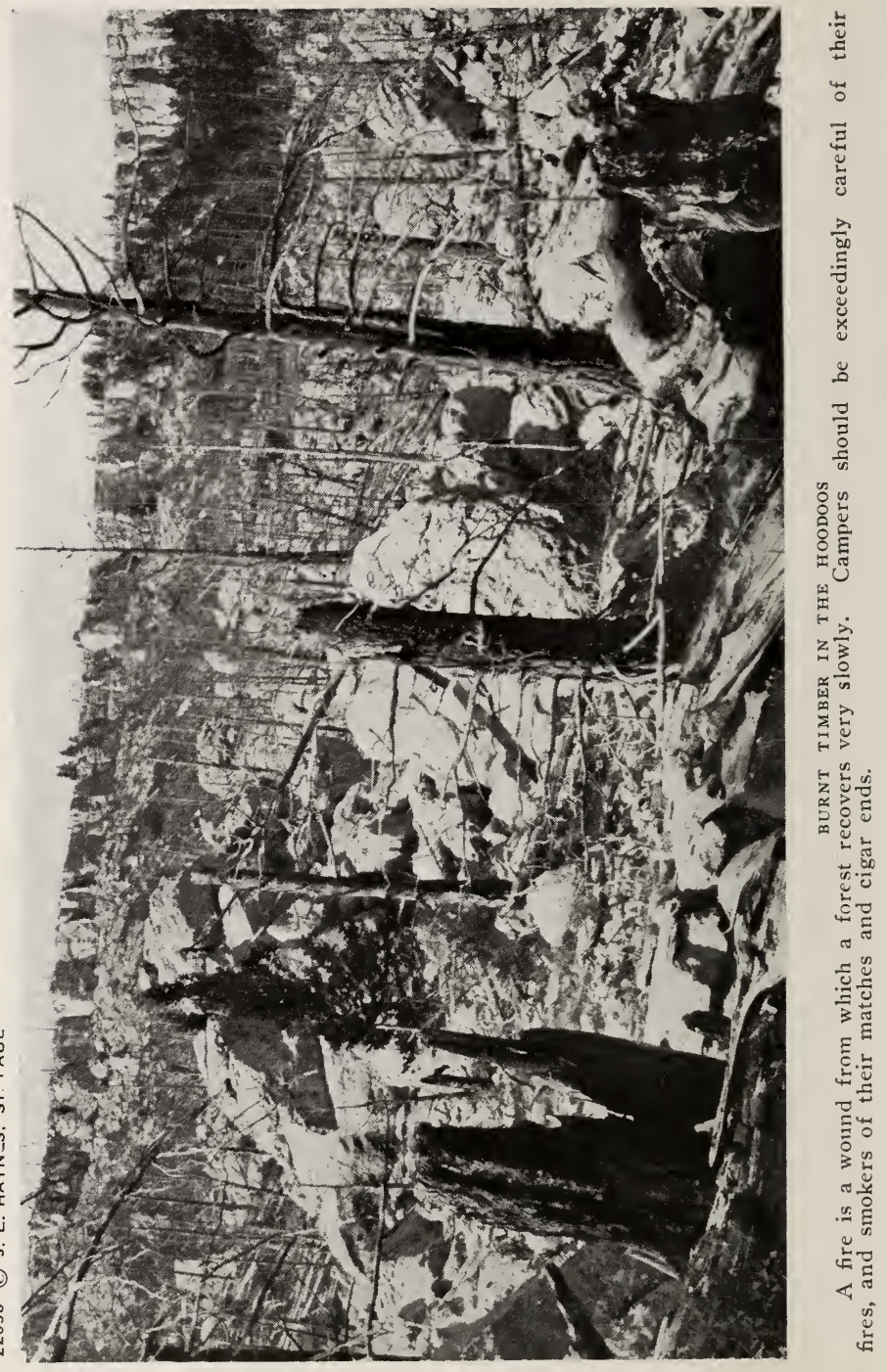




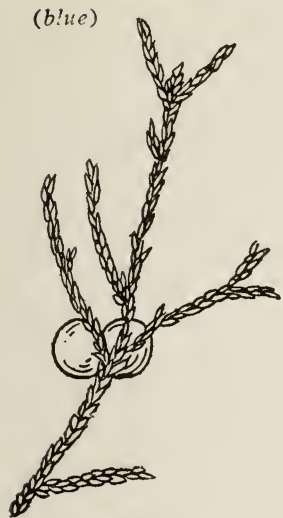

CEDAR

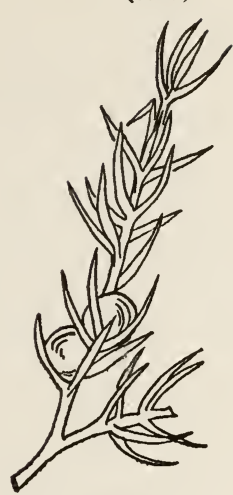

JUNIPER

Cedar "(Juniperus scopulorum). Like the limber pine, the cedar is a tree of the lower levels, being abundant around Mammoth Hot Springs but practically unknown on the park plateau. It occurs mixed with the limber pine on the hot springs formation and the surrounding hills, and also extends alone out on the drier slopes. It is a grotesque and crooked tree, with a gray bark that comes off in shreds. The leaves are very tiny and scale-like, and are pressed close to the twigs, completely covering them so that the wood can not be seen. The fruit is a blue or purplish berry, covered with a waxy white "bloom."

Juniper (Juniperus sibirica). Possibly this species should not be listed among the trees of the Yellowstone, for although it reaches tree size elsewhere, in the Park it remains a mere sprawling shrub. Its range is about the same as that of the limber pine and the cedar; an especially good place for observing it is on the terraces at Mammoth Hot Springs. Its leaves grow in much the same fashion as those of the cedar, but are sharp and needle-like. The fruit is quite similar to that of the cedar, averaging perhaps a trifle larger. 


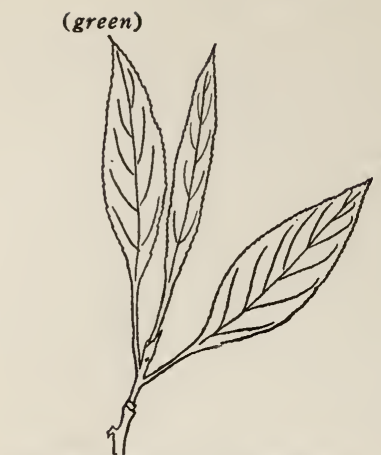

NARROW-LEAVED COTTONWOOD

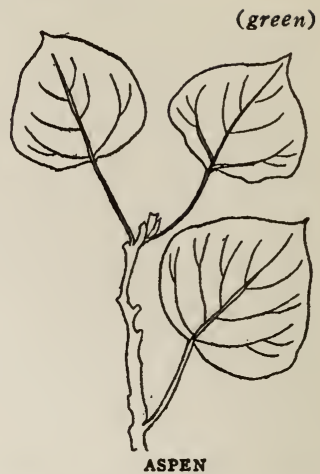

(Populus angustifoli$u s)$. This tree, although abundant along the streams of the approaches to the Park, is rare in the Park itself. The specimens at Mammoth Hot Springs were planted, as were also the few common or Eastern cottonwoods. The narrow-leaved cottonwood resembles the Eastern variety in size, and general habit of growth, being rather symmetrical when young, but developing irregularly as it becomes older. The bark, smooth on the smaller branches and young trunks, eventually cracks into rough furrows. The distinguishing feature of course is the narrowness of the leaves, which are frequently no wider than those of some of the broad-leaved willows.

Aspen (Populus tremuloides). The aspen, quaking-asp, or trembling poplar (it has a number of names) is found all over the Park, but most abundantly at the lower levels. It is conspicuous from its greenish-white bark, which is always scarred with black marks, the record of elk and deer browsings. The small, rounded leaves with finely toothed edges tremble on their long, flattened stems in the slightest breeze. The aspen is a "pioneer tree," occupying burned-over areas left by fires, and preceding other species into new lands being invaded by forest growth 


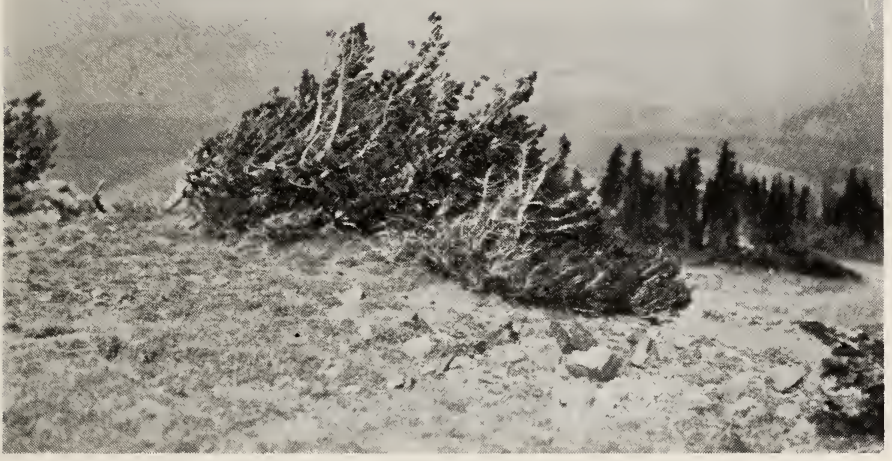

WINDBLOWN TREES AT TIMBERLINE

Near the mountain-tops the wind blows incessantly, and trees are reduced to mere sprawling bushes, with branches stretched out to leeward.

22705 (C) J. E. HAYNES, ST. PAUL

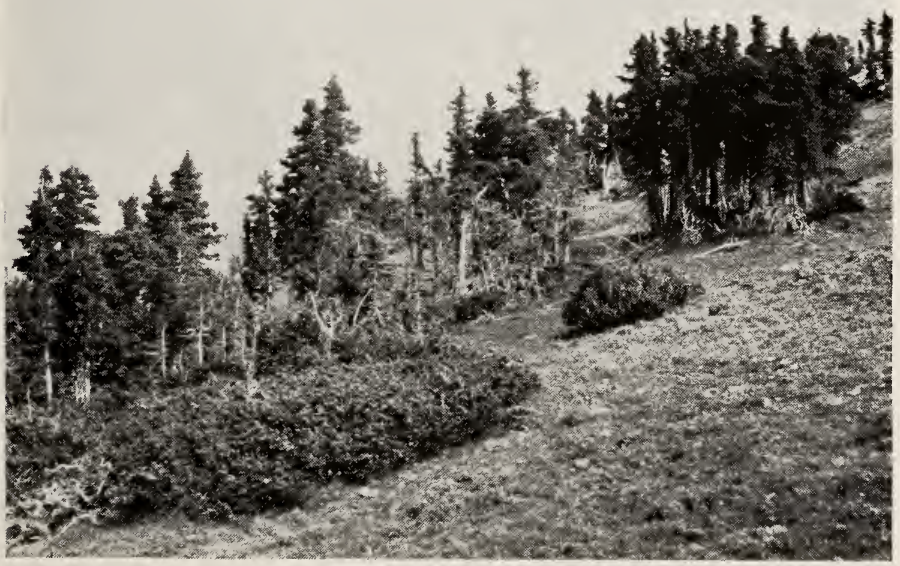

SPRUCES UNDER SUB-ALPINE CONDITIONS

A little below timberline the effects of the wind are not so marked, but snow forces the first growth of the trees to be a sprawling mat, Later the typical spire-shaped growth develops. 


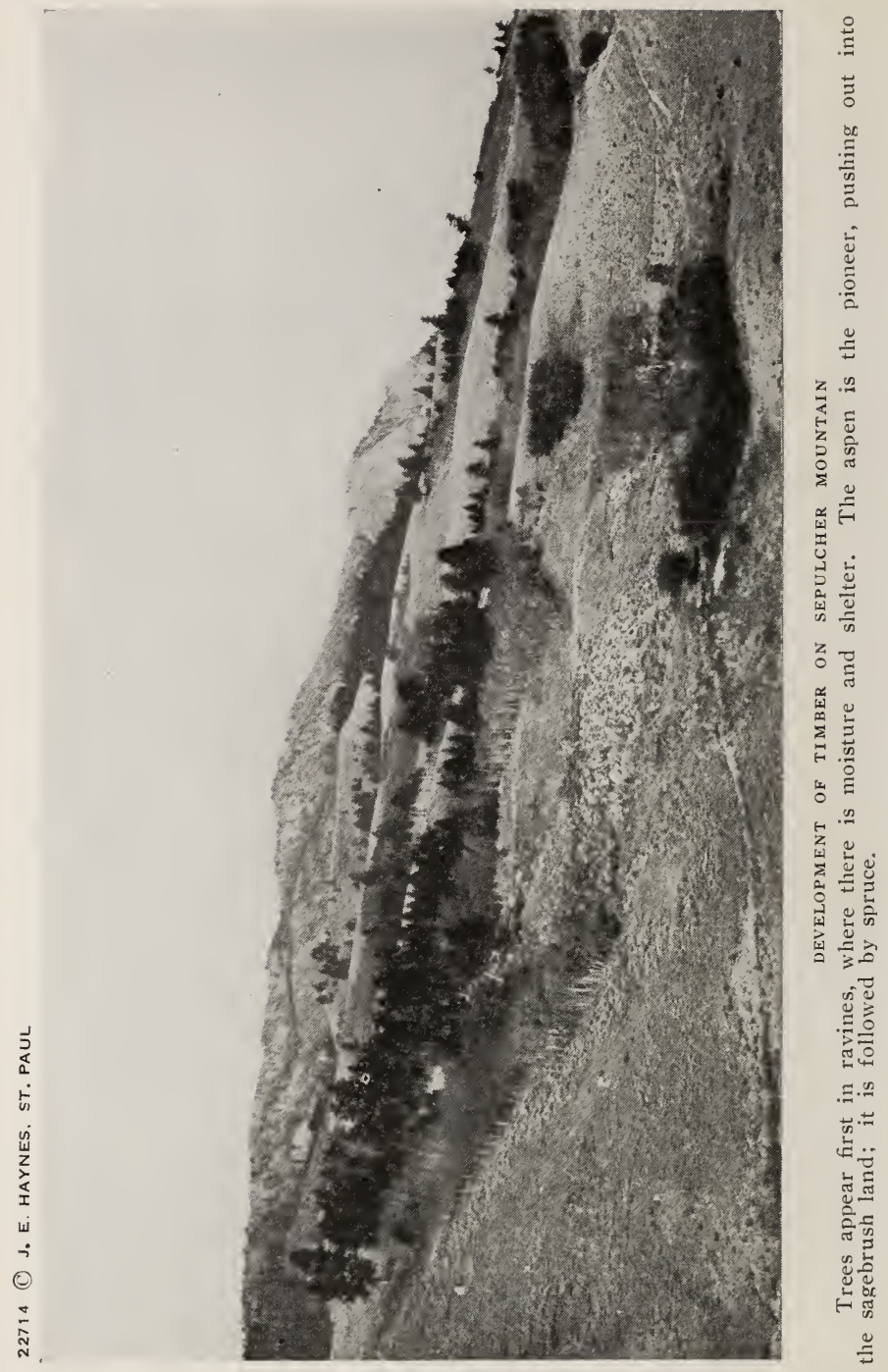


(green)
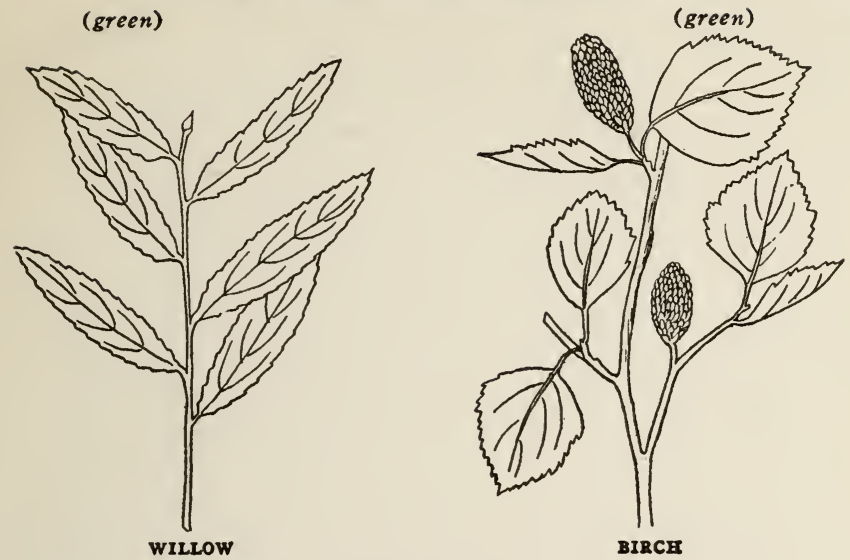

SHRUBS.

Willow (Salix). Willows, as well as a number of other plants that reach tree size at lower altitudes, must be classified as shrubs in Yellowstone Park. Even the few willow trees behind the hotel at Mam. moth Hot Springs are not native, but were brought in and planted. The shrubby willows are to be.found in great abundance near water-courses and lakes all over the Park. There are a number of species here, with leaves ranging from the very long and narrow, as in the long-leaf willow, to the broad and blunt, as in the peach-leaved species; but for practical purposes they may be lumped together under one head.

Birch $($ Betula). The birch found in the Park is a tall shrub, quite abundant along the water-courses and in little, moist valleys on the hillsides, particularly at the lower elevations. It commonly attains a height of fifteen or twenty feet. Its most striking feature is the glossy, dark-red bark, thickly set with horizontal white markings. The leaves are small and rounded, and finely toothed around the margins. The fruiting body is cylindrical, comparatively long and narrow. 

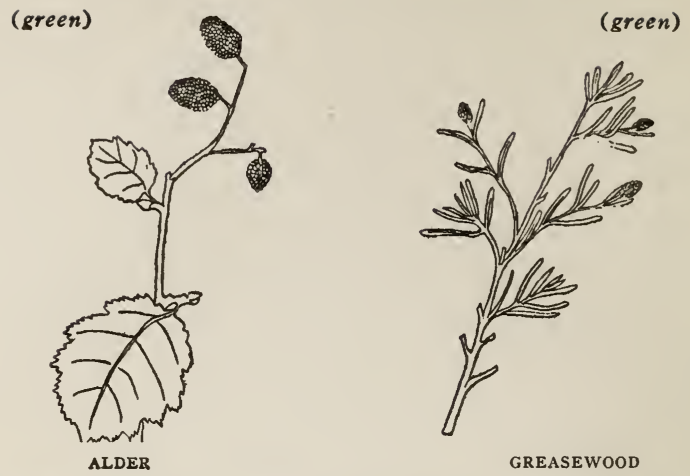

Alder (Alnus). Though the alder is not so abundant in the Park as is the birch, it is still fairly frequent in its occurrence, and has about the same distribution. It does not grow quite so tall as the birch, and the twigs are less slender and do not droop. The bark is a duller brown, and the leaves are somewhat larger and more coarsely toothed on the margins. The fruiting bodies are very characteristic. They are borne in clusters at the ends of the twigs, and their dried remains hang on to the branch for a year or more, instead of falling during the summer as do those of the birch. They may also be distinguished by their shorter and thicker form.

Greasewood (Sarcobatus). Though very abundant on Western plains, greasewood is rare in the Yellowstone Park, being found only in a few limited spots near the Gardiner entrance. This is because greasewood requires a high alkali concentration in the soil, which is lacking in most places in the Park. The plant is a low, somewhat spiny shrub, with gray bark and very narrow, fleshy leaves of a livid grayish-green color. They have also a decidedly salty taste. Throughout the West, greasewood is regarded as a sign of alkali soil, while sagebrush is considered a sign of soil good for farming if water is available. 


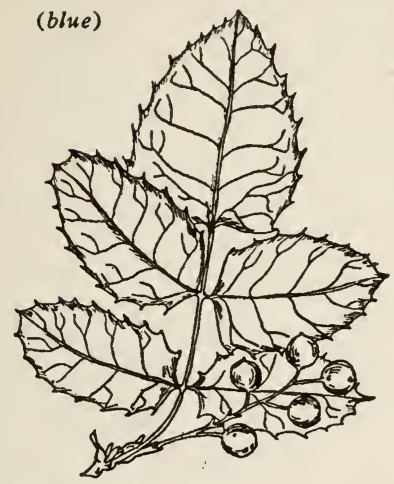

HOLLY-LEAVED BARBERRY (white)

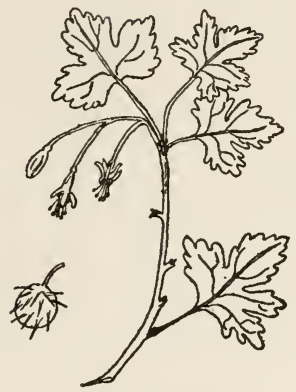

WILD GOOSEBERRY

\section{Holly-leaved Barberry (Berberis). The holly-} leaved barberry, or as it is sometimes called, Oregon grape, is found abundantly in the Park, creeping along on the ground under the timber, and among the taller shrubs on the sagebrush-covered hillsides. It is, indeed, so low and sprawling here as hardly to be recognized as a shrub at all. Its leaves are compound, each leaflet closely resembling a leaf of Christmas holly both in its sharp outline and in its stiff, leathery texture. The clusters of small, bright yellow flowers are succeeded by berries which remain green most of the summer, and finally turn blue or purple.

Wild Gooseberry (Ribes). There are several species of wild gooseberry in this region, and they are very similar to each other. They resemble the cultivated variety in most particulars, so that a detailed description is hardly necessary. Their yellow or yellowish-green flowers, borne early in the season, are followed by berries that turn purple or black, but are for the most part flat and disagreeable to the taste. Wild currants are found in the canyons and gullies with the gooseberries, and resemble them closely, except that their fruit is borne in stringy clusters instead of singly, and they have no thorns. 
(white)

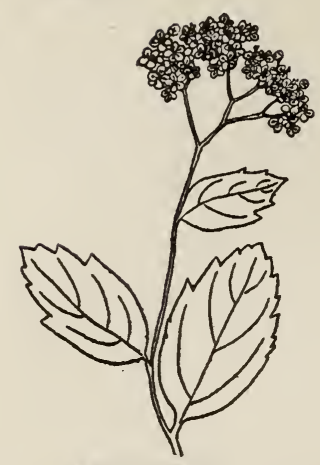

MEADOWSWEET

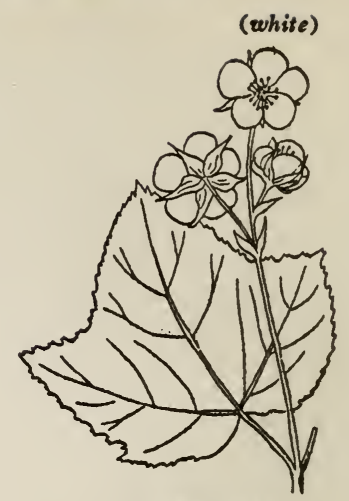

THIMBLEBERRY

Meadowsweet (Spiraea). This shrub is distributed along the edges of timber throughout the Park, and ventures a little into the open in moister places. It does not form a dense bush, but sends up its slender. stems singly or only a few together. The flowers are white and very tiny, and a large number of them mass together to form a close-set, feathery, flat-topped cluster. After the flowering season, a group of reddishbrown seed-pods still marks the plant. The leaves are oval in outline, with no teeth on the lower half and a few large, sharply pointed ones above the middle.

Thimbleberry (Bossekia). The thimbleberry, also called false raspberry, is closely related to the common cultivated raspberry. It is not found to any extent on the park plateau, but is fairly abundant in the shady ravines around Mammoth Hot Springs and at similar elevations. The plant is a low, thornless shrub with rather slender stems. The white flowers are large and showy, somewhat resembling those of the cultivated blackberry, and are borne either singly or a few in a cluster. The fruits resemble red raspberries, but are flatter in shape, rather soft and "mushy," and not so acid. The leaves are larger than those of the raspberry, but a little less deeply cleft. 
(yellow)

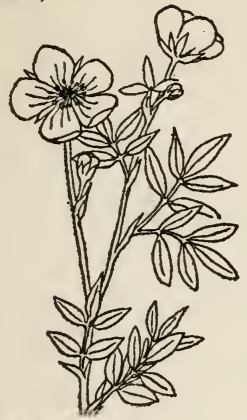

SHRUB CINQUEFOIL

(white)

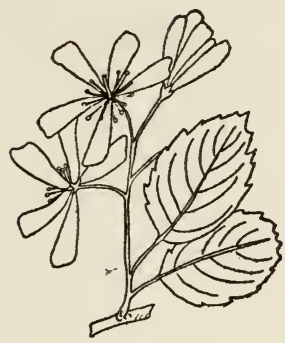

SERVICE-BERRY

Shrub Cinquefoil (Dasiophora). The sh r u b cinquefoil is fairly abundant at the lower levels on drier ground; it seems to thrive especially well on the limestone soil near Mammoth Hot Springs. It is a stiff, rather freely branching shrub, reaching a height of about three feet, although in very dry locations, as on the hot springs terraces, it may grow only a few inches high. The flowers are bright yellow, and continue in bloom throughout the season. The leaves are compound, the narrow, dark-green leaflets standing out like the fingers on a hand. All green parts of the plant are covered with a coat of silky hairs.

Service-Berry (Amelanchier). This is the Western representative of the bush known in the East also as shad-bush or Juneberry. It blossoms early, so that visitors during the main travel season are not likely to see it; however, during June and into early July its beautiful clusters of flowers, each with four long, white petals, make the shrub a conspicuous object on the open hillsides and at the margins of some of the forests. It is capable of a growth of twelve feet, but conditions are usually not sufficiently favorable to allow a height of more than three or four. The bark is smooth and gray, and the oval leaves, from one and one-half to two inches long, are sharply toothed. 

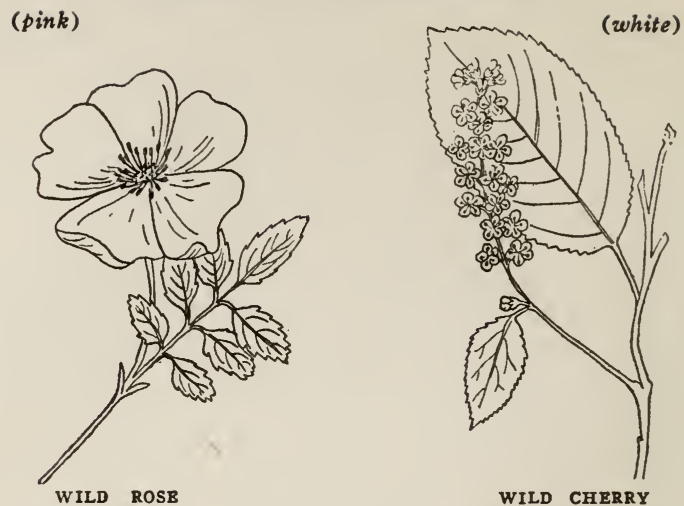

Wild Rose (Rosa). There are several varieties of wild roses in the Park, but since they cannot be distinguished except by an expert it is not worth while to define the differences between the species. The main characteristics that will be noted by most persons are that some have more thorns and others have a larger number of leaflets per individual leaf. The roses are very abundant along the stream courses, and in low places where moisture conditions are favorable. They come into bloom early in the season, and continue until late July or early August.

Wild Cherry (Prunus). In a few sheltered gulches, the wild cherry reaches almost a tree size, but in the open places where it is commonly seen, it is only a bush three or four feet high. Its small white flowers bloom early, and are borne in long clusters like currants, or the flowers of certain Eastern wild cherries. The fruit is green throughout most of the season, turning almost black just before frost. The taste is very strong and astringent, so that this species also bears the name of Rocky Mountain chokecherry. The bark is red-brown, showing some tendency to crack horizontally. The glossy green leaves are beset along the margins with very fine, incurving sharp teeth. 


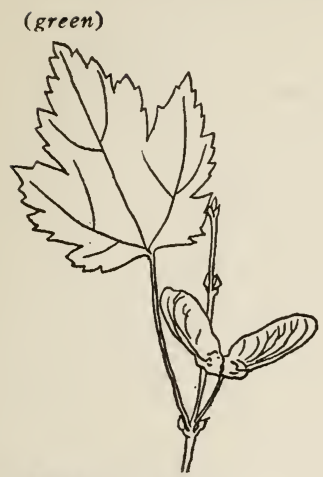

MOUNTAIN MAPLB

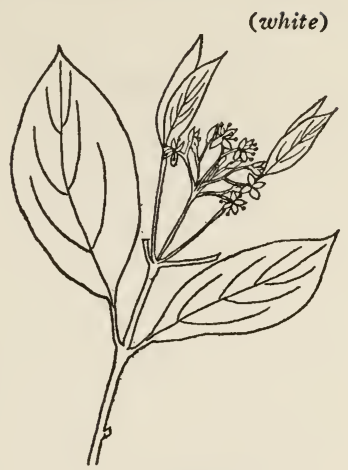

DOGWOOD

Mountain Maple (Acer). Unlike certain species already mentioned, which are shrubs in the Park and reach tree size at more favorable altitudes, the mountain maple is always a shrub. It is found only below the level of the park plateau, in the same moist gulches and stream valleys that the birch and alder inhabit. It grows to about the same size as the birch, but its twigs, though slender, do not droop. Its leaves and seeds are practically identical in appearance with those of the tree maples, and since the seeds remain on the trees all summer the plant is easily identified. The bark is light gray and smooth; it develops shallow furrows only on the larger stems.

Dogwood (Cornus). The common dogwood of the Yellowstone Park region is the same species as the osier dogwood of the East. The bush reaches an average height of about four feet, and is found only where there is abundant moisture; it is in a class with the willows in this respect. The early-blooming white flowers, small and crowded into dense, flat-topped bunches, are followed by waxy white berries. Leaves and branches are opposite. The leaves are somewhat oval in outline, but taper off to a sharp point; they are bright green above and pale beneath. The bark is brownish-red, furrowed with gray on the older stems. 
(white)

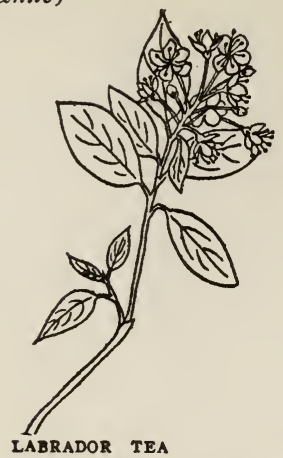

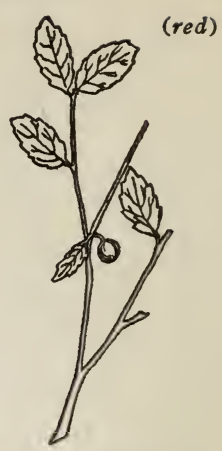

FUCKLEBERRY

Labrador Tea (Ledum). This is an exceedingly common shrub in the Park, growing mostly in the shade of the forests. It branches freely, and reaches a height of three or four feet. The creamy-white flowers grow in umbrella-shaped clusters, usually at the ends of the branches. The leaves are from one and one-half to three inches long, dark green on top and whitish and powdery underneath. Their edges are without teeth, and tend to curl backward toward the midrib. The green parts of the plant, especially the leaves, are more or less beset with resinous dots, and have a somewhat fragrant odor when bruised.

Huckleberry (Vaccinium). The huckleberry here is a very low, slender shrub, never exceeding a few inches in height. It is found only above the seventhousand foot level, on the park plateau, as a ground cover in somewhat open stands of lodgepole pine, such as occur around the upper geyser basin. In such places it grows literally as thick as grass, completely carpeting the ground. The slender stem is generally ridged or angled, and the green bark has a surface suggestive of finely pebbled leather. The leaves are small, thick and tough. The small, pinkish flowers blossom early, either singly or a few in a cluster, and are succeeded by berries that when ripe are a dark red. 


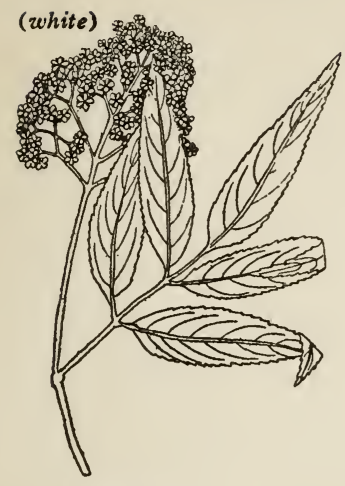

ELDERBERRY

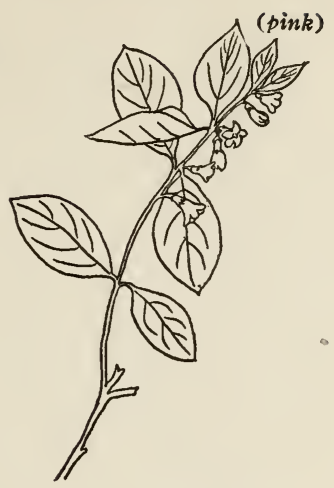

BUCKBRUSH

Elderberry (Sambucus). The elder is found only in shaded, fairly moist locations, mostly at the lower elevations. It is not so tall a shrub as the common elder of the East; six feet represents a rather extreme height. The stems are smooth, stout and hollow, with brown pith. The compound leaves have each from five to eleven narrowly lance-shaped leaflets, with finely toothed edges. The plumy white flowercluster is shaped like a blunt pyramid, instead of being flat like the common elder, and the berries when ripe are red instead of black.

Buckbrush (Symphoricarpos). This shrub has several common names, being known also as snowberry and wolfberry, and a form with red fruits bears the name coralberry. In the Park it has about the same distribution and choice of habitat as the elder. The bush is of only medium height, seldom exceeding three feet. The leaves are from one inch to two and onehalf inches in length, smooth and thickish, with smooth margins, oval and somewhat pointed. The small, cupshaped flowers are pink, a cluster appearing above each leaf along the stem. The berries are waxy-white, a quarter of an inch or more in diameter. During the fall they make the bush very conspicuous. 


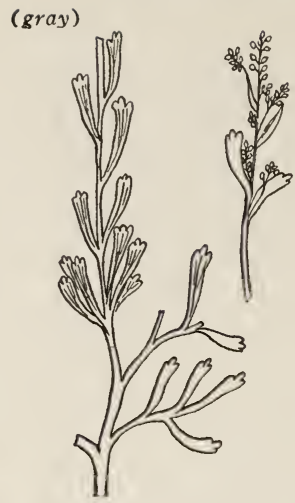

SAGEBRUSH

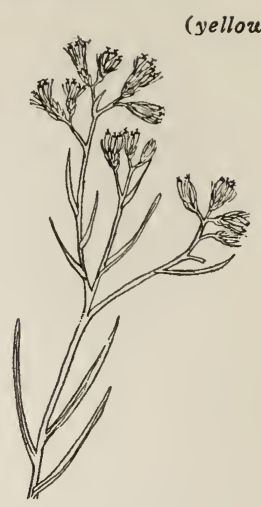

RABBIT BRUSH

Sagebrush (Artemisia). Sagebrush is the dominant shrub in all open places in the Yellowstone Park, as it is throughout the West. In its most frequent form it is a round bush two or three feet high. As a rule the plants do not form a continuous cover, but are spaced some little distance apart, giving the plain or hillside where they grow a curious tufted appearance. The prevailing color is gray; the bark is gray, the narrow leaves are gray, and the tall flower-spikes that appear late in the season are gray also. It is this that makes most Western landscapes so sad-colored.

Rabbit Brush (Chrysothamnus). This shrub, known also as golden bush and rayless goldenrod, is a companion plant of the sagebrush at the lower elevations, but is not found much above the 6,500 foot level. It commonly reaches a height of two feet or a little over. As a rule, only the base of the plant is woody, the abundant straight upper branches being soft and green. The leaves are very numerous and are exceedingly narrow and pointed. Their bright green color gives a welcome relief from the prevailing sagebrush gray, and when the yellow flower-heads bloom, about mid-August, the bush is really beautiful. 

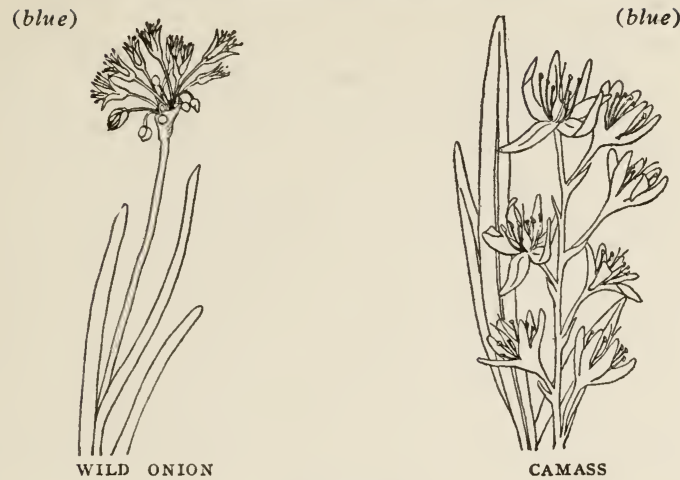

\section{HERBS.}

Wild Onion (Allium). There are several species of wild onion in the Park, but they resemble each other so closely that a single description will suffice for all of them. The flowers are generally purple, but there are also blue species and even white ones. They are grouped into small, round-topped clusters at the summits of smooth, round stems between six and twelve inches in height. The leaves are round and hollow, like those of cultivated onion, but more slender. The flavor and scent are comparatively mild.

Camass (Camassia). The camass, a very beautiful plant of the lily family, is found very abundantly in moist places. From an underground bulb there arises a group of narrow, lance-shaped, parallel-veined leaves about six or eight inches long, and in the midst of these is the flower-stem or scape, twelve to fifteen inches high. There are a dozen or so flowers on the stem, each a delicate, lily-shaped bloom with narrow petals about three-quarters of an inch long, of a strong, bright blue color. The bright yellow pollensacs of the stamens make an effective contrasting touch. Camass bulbs were formerly a staple article of food among the Indians, and are still much sought after by bears. 


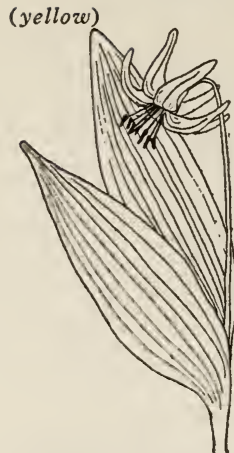

DOGTOOTH VIOLET (white)

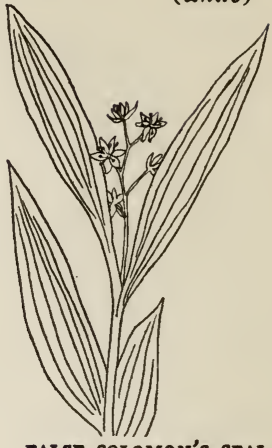

FALSE SOLOMON'S SEAL

\section{FLOWERS.}

Dogtooth Violet

(Erythronium). This species should properly be called spring lily, for it belongs to the lily family and is not a violet at all. It is found in great numbers throughout the timbered areas of the Park, blossoming early and disappearing before mid-July. From between the two broad lance-shaped leaves there arises a slender stem, bearing a single bright yellow flower with six narrow petals, which usually curve backward. The diameter of the flower is about two inches. It is succeeded by a three-sided, club-shaped pod containing numerous seeds; this is green at first and turns gray as it ripens.

False Solomon's Seal (Smilacina). False Solomon's seal is fairly frequent in the Park, in wellshaded woods and ravines. An unbranched, bowed stalk bears two rows of alternately arranged leaves. These are lance-shaped and without stems, their bases being set directly on the stalk; the veining is parallel. The flowers are white and very tiny, and are grouped into a feathery cluster at the end of the stem. They come early in the season, and are gone by the tenth or fifteenth of July. The berries are light green, almost white, with black stripes running from top to bottom. 
(blue)

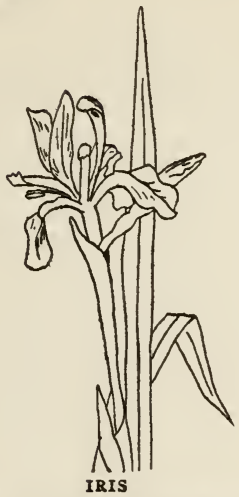

(blue or white)

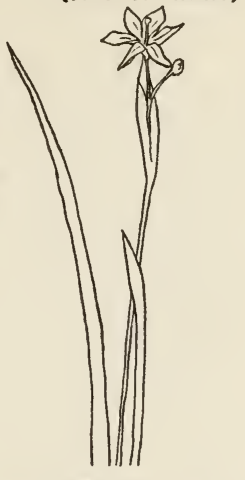

BLUE-EYED GRASS

Iris (Iris). This beautiful flower, close kin to the old-fashioned "flag" of our grandmothers' gardens, is frequent in the Park along the stream courses. The light-green leaves, rising from the thick underground rootstock, are folded inward and the inner sides pressed so firmly together that they seem to grow that way. The leaves thus present a very stiff sword-like appearance, with the edges instead of the sides toward the flower-stem. The stem is longer than the leaves, bearing one or two flowers. The petals are considerably more slender and delicate than those of the cultivated iris, and are blue or light purple in color, marked with yellow.

Blue-Eyed Grass (Sisyrinchium). Blue-eyed grass belongs to the iris family. It is found in moist, but not wet, places throughout the Park, blossoming during the earlier part of the summer. The leaves are about three or four inches long, grass-like and stiff, with their edges toward the stem. The stem, about a fourth longer than the leaves, is flattened, sometimes having thin wings or extended edges. Each stem bears from one to three six-pointed, star-shaped flowers a little less than one-half inch across, and ranging in color from deep blue to white. 


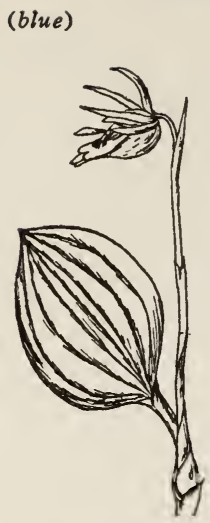

SPRING ORCHID

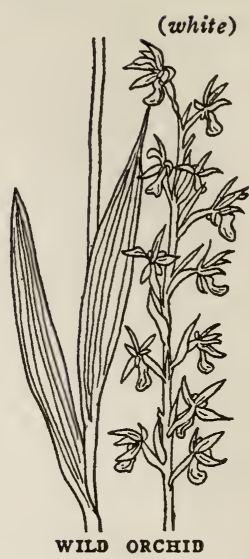

Spring Orchid (Calypso). There are several vari-
of wild orchid in the Park, of which this is pereties of wild orchid in the Park, of which this is perby those who visit the Park early in the season, for its period of bloom is over by July 10 at latest. There is a single broad oval leaf near the ground, above which rises the three or four-inch flower stem, bearing one nodding, rose-colored flower. This is somewhat over an inch in length, and of an irregular shape. There is a central boat- or slipper-shaped section, above which project four narrow, twisted petals. This plant is found only in very moist woods.

Wild Orchid (Limnorchis). This plant may be taken as more typical of the wild orchids of this region. There is a central thick stem bearing several stiff, sword-shaped leaves and having a group of similar leaves at the base. The upper part of it bears a spike of small flowers more or less similar in shape to the larger flower of the spring orchid. In the wild orchid these flowers are white; in the closely related Coral-Root (Corallorrhiza) there are no leaves at all, the stem and outer petals are coral-red and the inner part of the flower is white mottled with red. 
(white)

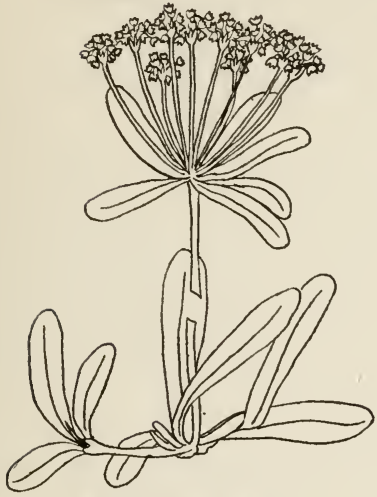

WILD BUCKWHEAT (pink)

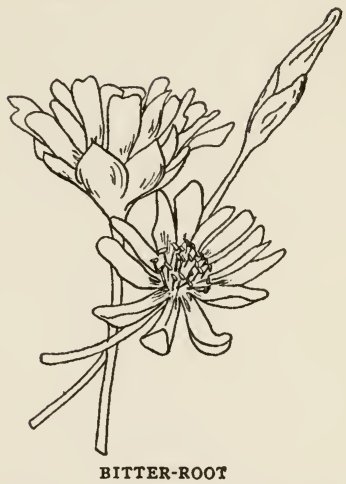

Wild Buckwheat (Eriogonum). This plant, called also "umbrella plant" because of the shape of the flower cluster, belongs to the open, dry places; it is usually part of the undergrowth among the sagebrush. From an underground woody rootstock there grows a sprawling mass of slender stems with small, narrow paddle-shaped, powdery gray leaves. The slender flower-stems stand about eight inches high, divided at the top into a group of smaller stems like the ribs of an umbrella, which support a rounded cluster of very small flowers. Generally these are white; one species, with yellow flowers, is called Sulphur Plant.

Bitter-Root (Lewisia). The bitter-root is one of the most conspicuous and beautiful of the early-blooming flowers of the open places. Its favorite locations are dry, timberless hillsides. A rosette of smooth, narrow leaves springs from a thick, fleshy root, lying flat and close to the earth; and from the midst of this the almost stemless flowers rise. They are very delicate and beautiful; their petals, usually six or eight in number, are each an inch or more long, and range in color from white to almost red. The most common color is a clear rose tint. 
(yellow)

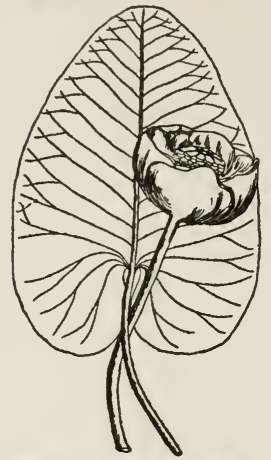

YELLOW WATER LILY (cream)

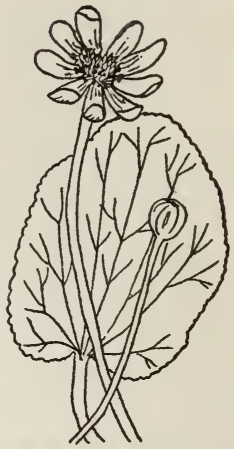

MARSH MARIGOLD

Yellow Water Lily (Nuphar). People generally think of mountain regions as places of steep slopes and rushing torrents, and water lilies in the mountains seem almost out of place. But even mountain streams are interrupted occasionally by quiet little lakes, and here water lilies make their home. The large white water lily of the East does not occur in this region, but a smaller yellow water lily is abundant. It comes into bloom early in July, and continues until frost.

Marsh Marigold (Caltha). Along the margins of the water lily ponds, and in many other moist and. marshy places in the Park, this species abounds. Almost always its roots, and frequently even part of its stems, are under the surface of watery muck. The stems, thick, fleshy and hollow, branch into a rather bushy structure from eight inches to a foot in height. They bear a large number of thickish, round leaves from two to four inches across. The flowers bear a strong resemblance to buttercups, except that they are white, slightly tinged with blue on the outside. The plant is very similar to the Eastern marsh marigold, except for the color of the flowers, which in the Eastern species is bright yellow. 
(yellow)

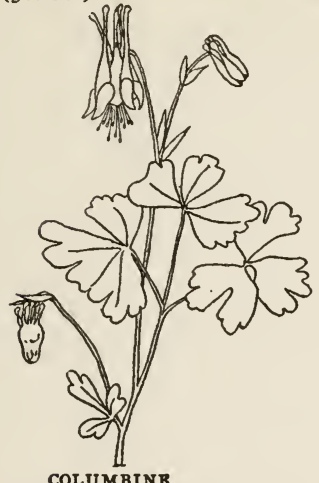

(blue)

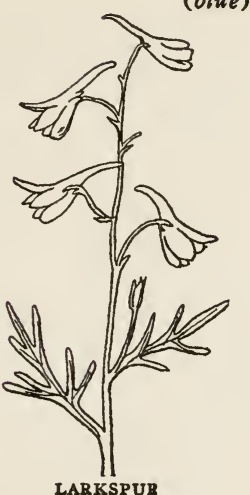

LARKSPUR

Columbine (Aquilegia). The columbine is one of the most abundant and most beautiful of the flowers in the Park. It is found in all moderately moist places, even to the summits of the mountains, and blooms from early in July until well into August. The leaves are trefoil, somewhat like those of clover, but the sections have rounded lobes on their outer ends. The flowers are very characteristic: Five spurs project from the bases of the petals, each with a tiny ball on the end. The upper part of the flower resembles somewhat a double frill, the inner five parts being rolled into little funnels. All the columbines in the Park are yellow, sometimes marked with red.

Larkspur (Delphinium). The larkspur grows very abundantly in open, sunny places that are welldrained but not too dry; it does not belong to the sagebrush association. The thick, smooth, light-green stem is fairly tall, growing three feet or sometimes more, and ending in a spike of flowers. The leaves are cleft into about five narrow segments, which extend like the fingers of a hand; each segment ends in three or five pointed projections. The flowers are somewhat irregular, the upper part extending backward into a spur, which gives the plant its name. 


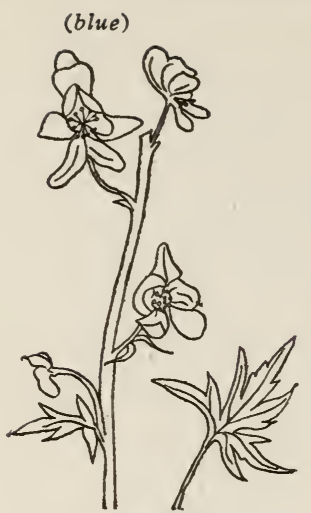

MONKSHOOD

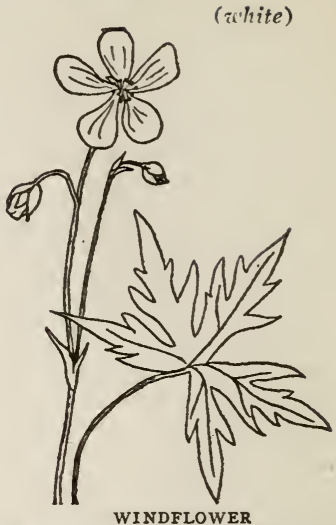

Monkshood (Aconitum). Monkshood is closely re-
do larkspur, but is found in much moister places, lated to larkspur, but is found in much moister places,
though still seeking the open. The size and general manner of growth of the two plants is similar, and they both remain in bloom from early in July until at least the end of August. The leaves of the monkshood are cleft like those of the larkspur, but the segments are somewhat broader. The flowers, dark blue or purple in color, are irregular, but not in the same manner. The spur is short and curved under, or even entirely lacking. The upper part of the flower is formed into a sort of a hood, which resembles the cowl of a monk.

Windflower (Anemone). The anemone is one of the earlier-blooming flowers, and is usually gone by the middle of the season. It occurs at all levels in the Park, in moist and usually shady places. Most of the leaves are grouped in a cluster on the ground. Ther are cleft into wedge-shaped segments, usually three, but in some varieties as many as seven, the ends of which are lobed. The flowers are regular in outline, but the number of parts varies from four to twenty. There are several species of anemone, some with blue, others with white flowers. 

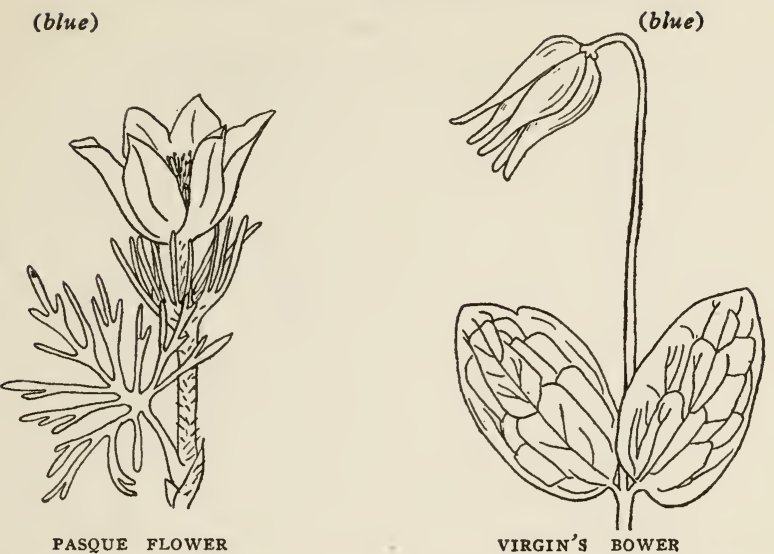

Pasque Flower (Pulsatilla). The word "Pasque" signifies "Easter"'; this is one of our earliest flowers. It is properly a plant of the plains and prairies, and is found in the Park only at the lower levels, on graveled hillsides. The leaves are arranged in a basal rosette; they are very hairy, and in outline resemble those of the windflower, except that the sections are much narrower. From the midst of the leaves rise one or several stems about four inches high, each bearing a single large, cup-shaped, purplish or whitish flower, with from five to seven petals and a mass of yellow stamens within.

Virgin's Bower (Clematis). This plant occurs in many places, always in moderately moist, well-shaded woods and thickets. The leaves are oppositely arranged and shaped much like the leaves of the lilac. The petals of the flower are dark blue or purple, forming a cup at the base and their points extending straight forward. This is another early-blooming flower, its season being over before the first of July. Another clasely-related species of clematis has very finely-divided, somewhat hairy leaves; it is known as Leather-Cup. 
(yellow)

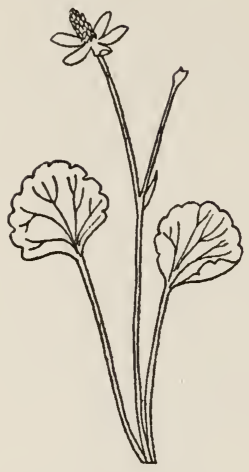

BUTTERCUP (blue)

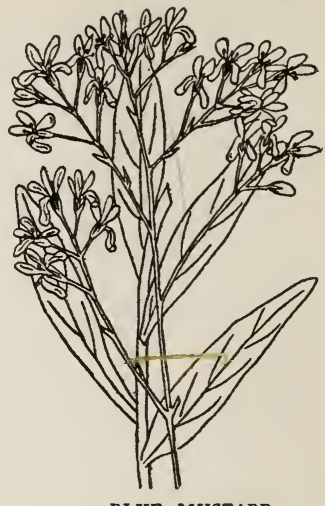

BLUB MUSTARD.

Buttercup (Ranunculus). Buttercups are numerous in the Park, seeking moist places, both in the open and in partly shaded locations. They blossom early, and continue until nearly the middle of the season, where conditions are favorable. There are several kinds of buttercups to be found: the common, yellow-petaled kind, the so-called abortive buttercup with petals so small as to be invisible, and one exceed. ingly interesting little plant with round leaves, that is found growing right in the streams of warm water running from the hot springs.

Blue Mustard (Thelypodium). This plant is a fairly frequent roadside weed, especially in dry places at the lower elevations. It is abundant near Mammoth Hot Springs. It is a somewhat bushy plant, about eighteen inches or two feet high, with stout, tough stems. There is an abundance of small blue or purplish, four-petaled flowers, borne at the ends of the branches, giving the whole arrangement a rounded or umbrella-shaped appearance. The flowers are succeeded by seed-pods, long and very slender, which point upwards on their curved stems. The plant is in bloom during July and part of August. 
(red)

(yellow)

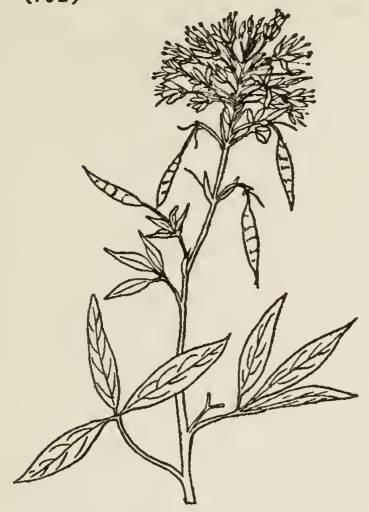

BEE PLANT

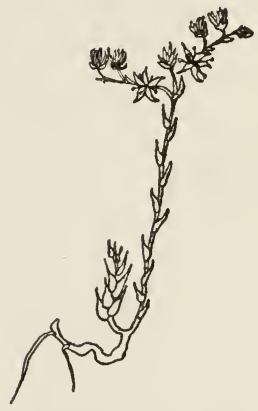

STONECROP

Rocky Mountain Bee Plant (Cleome). This is one of the most common roadside plants, especially in open, gravelly soils at the lower levels. It has a central stem a foot or two high, with several loose branches, each ending in a flower-cluster. The leaves are compound, with three moderately long, narrow, pointed parts. The magenta flowers, each with four petals, are grouped into a dense, round-topped cluster. The lower flowers in the group blossom earliest, so that before the last buds in the center have opened the long, drooping green seed-pods have begun to develop. Blossoming begins early in July and lasts until frost.

Stonecrop (Sedum). The stonecrop is one of the most peculiar plants in this region, in its adaptation to, and indeed apparent preference for, extreme desert conditions. It is found only in the most arid situations. A favorite habitat is the face of some bare, hot rock, with only a spoonful of earth in a crevice to afford a roothold. The flat-lying stems are round and fleshy, and the many small, peg-shaped, pointed leaves are thick and fleshy also. The flower-stems are about three inches high, dividing near the top and bearing a compact, flat-topped cluster of bright yellow flowers. 


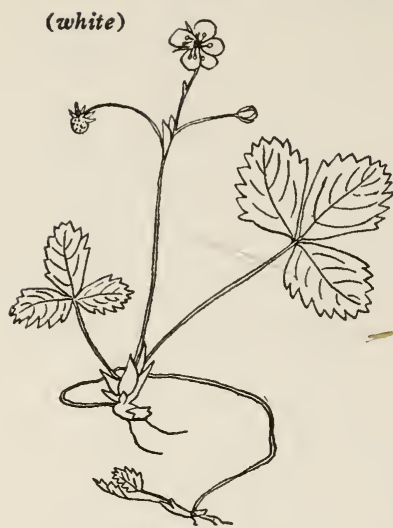

WILD STRAWBERRY

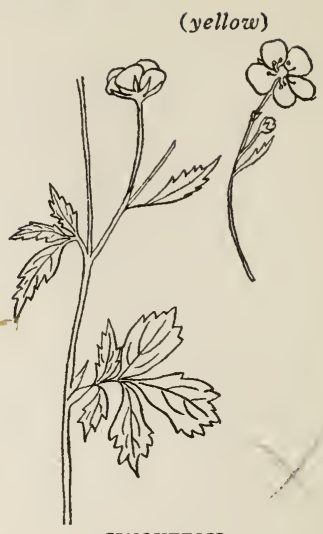

CINQUEFOIL

Wild Strawberry (Fragaria). Wild strawberries are frequent in the Park, in well-shaded, moist ravines where soil conditions are good. The leaves, grouped into a basal rosette, are trifoliate, like the leaves of clover. The margins of the leaflets are smooth toward the base, but above the middle are edged with sharp teeth. The flower stalks are as long as or a little longer than the leaves, and bear several five-petaled, white blooms. The plant continues in blossom throughout the season, even after it has ripened some fruit. The berries are uncommonly fine-flavored, but usually the bears are the first to find them.

Cinquefoil (Potentilla). There are several species of cinquefoil in the Park, but they resemble each other sufficiently to be treated under one head. The leaves are compound, usually with five to seven leaflets radiating like the fingers of a hand, but there is at least one species with the leaflets arranged featherwise along a central stalk. The leaflets are lanceshaped, broadening somewhat toward the outer end, and toothed along the margins. The flowers are yellow, with five petals, and from ten to thirty stamens; they remain in bloom from June until late August. 
(blue and white)
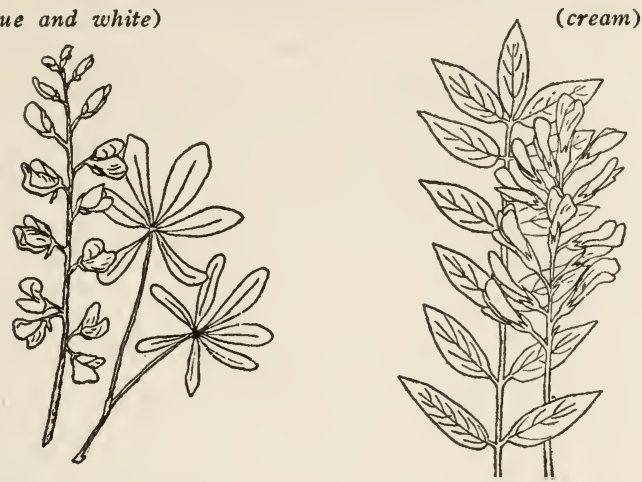

LUPINE

LICORICE

Lupine (Lupinus). The lupines are among the most striking and handsome of all the flowers in the Park. They are found at all levels, in open and partly shaded situations, preferring gravelly, well-drained soils. The stems are stout and erect, from one to three feet high, ending in the flower spike. The leaves are compound, with from five to ten narrow, entire-edged leaflets arranged finger-fashion. The pea-shaped flowers, usually bright blue, but sometimes marked with white or even entirely white, are thickly clustered around the axis of the spike. They are in bloom from June until September.

Licorice (Glycyrrhiza). This plant is frequently found along the roadsides, especially in the lower levels of the Park. It has rather stout stems about two feet high, bearing quantities of smooth, green compound leaves, with from eleven to nineteen oval leaflets. The flowers resemble those of the pea, but are somewhat narrow and long. They are grouped in dense clusters at the upper ends of the flower stalks, which rise from the axils of the leaves. They are yellowish-white in color, and their season lasts from early July until late August. The pods are covered with hooked prickles, so that the plant is sometimes called "burr-pod." 
(blue or white)

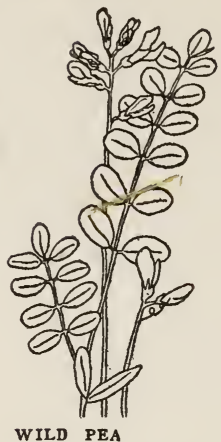

(blue or white)

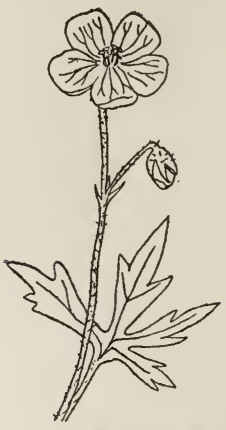

GERANIUM

Wild Pea (Vicia). There are many kinds of wild pea, but in general appearance they are all alike. They are long, loosely sprawling plants, tending somewhat toward the vine habit, with tendrils at the ends of their long, compound leaves. The flower-stalks rise from the angles of the leaves, bearing several pea-shaped flowers. These are of various colors, from purple to white, but the darker colors predominate. The flowers are followed by small pea-like pods containing a number of smooth little seeds. The wild pea prefers moist situations, and is in bloom during July and August.

Geranium (Geranium). This plant, known also as cranesbill, is abundant in the moist woods throughout the Park, and also occurs freely in treeless places where there is sufficient water. The stem rises from a basal group of leaves, and is itself somewhat leafy. The leaves are cleft almost to the center into four or five sections, and each section is again notched or lobed. The flowers, averaging an inch or a little less across, have five broad petals and ten stamens. There are two species of geranium in the Park; one, slender and somewhat smooth, bears white flowers; the other, stouter and coarser, is hairy and very sticky, and has purple flowers. They are in bloom throughout the entire season. 
(blue)

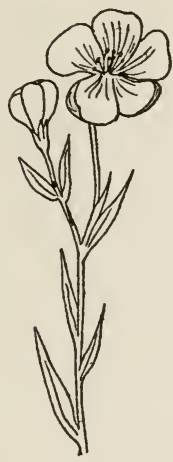

FLAX

(blue)

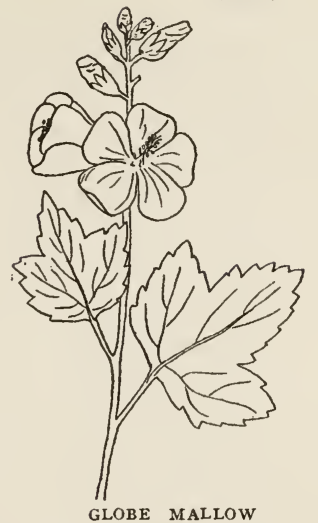

Flax (Linum). Wild flax, one of the most delicate and beautiful of our wild flowers, frequents the open, moderately dry places throughout the Park. Its stem is very slender, branches but little or not at all, and is from eight to twelve inches in height. The numerous leaves, distributed along the stem almost up to the flowers, are very narrow and pointed, and stand up at a sharp angle with the stem. The flowers, from one to five in number, blossom one at a time in a group at the top. They are about an inch in diameter, with five broad petals, and in color are a strong, pure blue.

Globe Mallow (Sphaeralcea). This plant is found only along stream courses and in other moist places, and always in the open. It is fairly frequent along the run-off streams from the Mammoth Hot Springs. There may be one or several stout stems, about three feet high, rising from a basal group of leaves, and bearing the flowers scattered along their upper halves. The leaves are shaped somewhat like maple leaves, but are rather hairy. The pale rose-purple flowers look like small hollyhocks; they last from early in July until about mid-August. 
(blue)

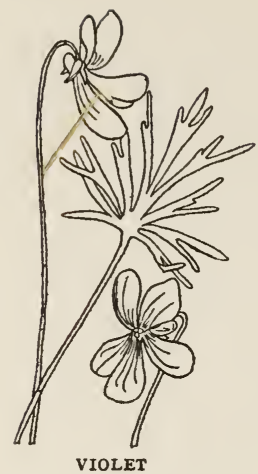

(cream)

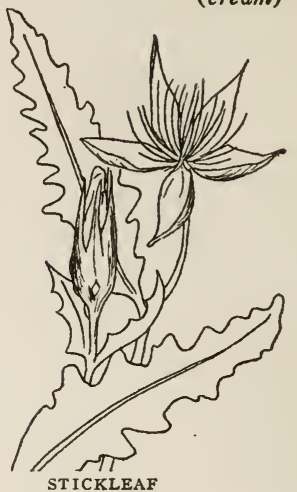

Violet (Viola). The violet, one of the most familiar and widely distributed wild flowers of the world, is very abundant in the Park, occurring generally in moist, shady places. There are several species of both the blue and yellow violets, but only an expert can distinguish them. At this altitude, the violet has a most remarkably late blossoming season, lasting almost until August in favored spots.

Stickleaf (Mentzelia). This plant has a limited distribution in the Park, being found only below the 6,500 foot level and in exceedingly dry places where the soil is loose and sandy. It is so striking in appearance, however, and so peculiar in other respects as to merit particular mention. It is a stout, loosely branching, bushy herb, about a foot or eighteen inches in height. The leaves are lance-shaped, with a few large teeth projecting from the sides, giving an outline somewhat like small thistle leaves. They are thickly covered with tiny hooked bristles that cling to anything they touch; hence the common name. The flowers are about three inches in diameter, with usually five or ten light yellow petals and very numerous long stamens. They open at night and close in the daytime. Blossoms during July and August. 
(cream)

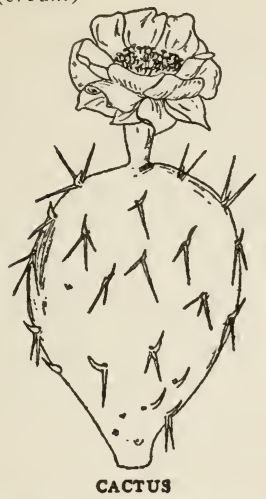

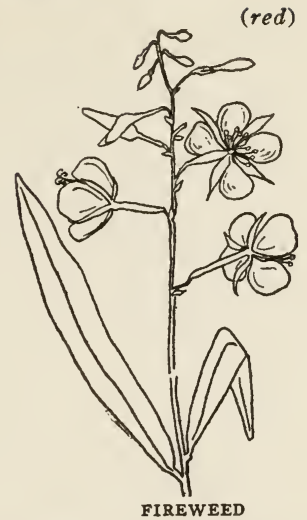

Prickly Pear Cactus (Opuntia). Cactus is exceedingly rare in the Park; it is found only on one or two dry plateaus, and occasionally also near the Gardiner entrance. The flattened joints, which many people call leaves, are really thickened stems. This plant has apparently almost lost the ability to produce leaves; a few small, mouse-ear-like growths occasionally appear near the thorns or at the base of the flowers. The flowers look somewhat like small water-lilies, with many beautiful yellow or cream-colored petals. They are followed by a pear-shaped red fruit, covered with nests of villainous microscopic prickles and filled with seeds and a juicy pulp.

Fireweed (Epilobium). The fireweed, one of the most widely distributed plants in temperate regions, is exceedingly abundant in the Park, making all the roadsides a blaze of color during August. The plant is two or three feet high, freely branching, forming a rather bushy growth. The leaves are lance-shaped, with untoothed margins, from two to about four inches in length. The flowers are borne in loose spikes on the upper parts of the branches. They average about an inch across, have four petals, and are of a rich purplered color. 


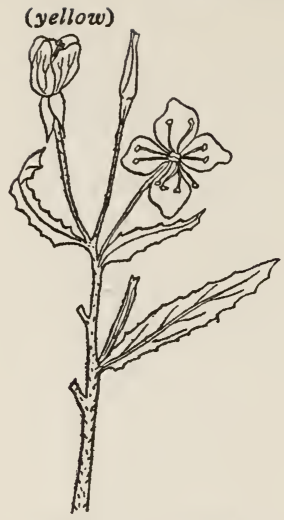

EVENING PRIMROSB

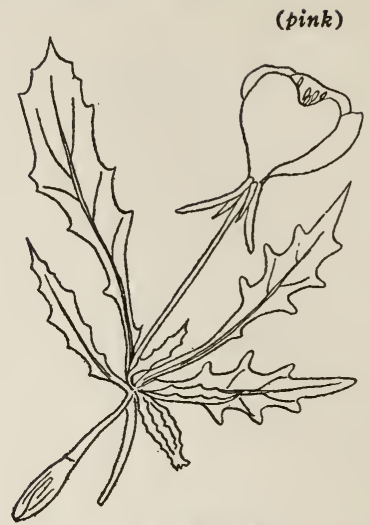

ROCK ROSB

Evening Primrose (Onagra). The evening primrose is fairly frequent along the roadsides, particularly at the lower elevations, in well-drained, moderately dry soils. The plant is usually between one and two feet high, with stout, tough, branching stems. The leaves are lance-shaped, on short stalks. The bright yellow flowers are distributed along the stem among the leaves; they have four broad-ended petals and are somewhat longer-stalked than are the leaves. Blossoming lasts from early July until about mid-August. The seed-pods are long and slender and split in four directions when they are ripe.

Rock Rose (Pachylophus). The rock rose belongs to the evening primrose family. It is found only in very dry soils, generally gravel banks, below the 6,000 foot level. There is a basal rosette of leaves, lance-shaped in general outline, with slightly irregular, wavy margins. From the midst of these rise several short-stemmed flowers, three inches or a little less in diameter, of a beautiful rose color. The season for rock roses is soon over, lasting only until early in July, but sometimes after the early fall rains a second crop of flowers will appear. 

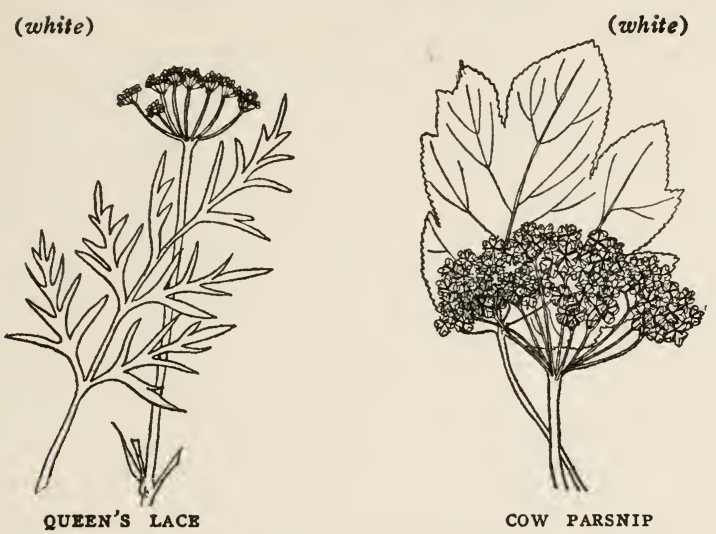

Queen's Lace (Pseudocymopterus). This plant belongs to the umbellifer or carrot family, and is found in moist places throughout the Park, especially where there is some shade. Its slender, smooth, branching stems reach a height of two or three feet (in the open somewhat less), ending in an umbrella-shaped head of lacy white flowers from two to four inches in diameter. The leaves are very finely dissected, like those of the carrot. The blossoming season lasts from early July into early August. A somewhat larger plant with similar flowers but with large compound leaves having lance-shaped leaflets, is known as Angelica.

Cow Parsnip (Heracleum). The cow parsnip also belongs to the carrot family. It occurs in moist places, but is much more abundant in open meadows than is queen's lace, though it thrives in partly shaded habitats as well. It is one of the largest of the herbs, with great, coarse, ribbed, hollow stems frequently four or five feet high. The leaves are huge, broad, hairy affairs, as much as a foot wide; they are compound with usually three divisions, and these are further cleft or divided. The flower-cluster is umbrella-shaped, from four to six inches across, yellowish. white in color. 
(blue)

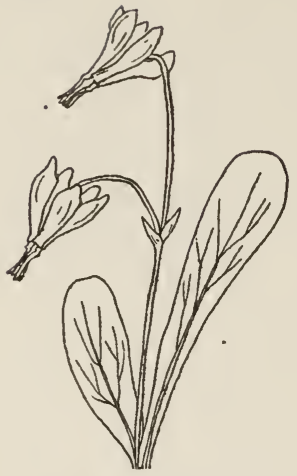

SHOOTING STAR

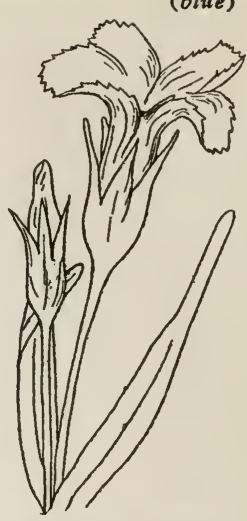

FRINGED GENTIAN

Shooting Star (Dodacatheon). This flower is one of the most interesting and beautiful of the early. blooming species; it might be called the American cyclamen. It is abundant in open, moist woodlands during June. From a basal rosette of smooth, thick. ish, paddle-shapeed leaves there arises a straight, slender flower-stalk about six inches high, bearing at its upper end a cluster of four or five nodding flowers. These are of a most singular structure, their long, narrow petals being turned sharply back and twisted, as though the flower were shooting through the air.

Fringed Gentian (Gentiana). The gentian, which is the state flower of Wyoming, is exceedingly plentiful in moist meadows and on streamsides throughout the Park. The slender stems, sparsely branched, reach a height of about one foot, bearing a few oppositely-arranged, broad-based, pointed leaves. The four darkblue petals are tightly twisted together when the flower is in bud, and even after it has opened their lower portion is still overlapped and folded into a deep tube. The upper ends bend outward, and are notched into slight fringe or deeply-toothed edge. 


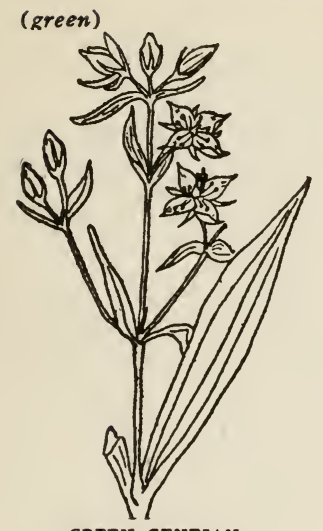

GREEN GENTIAN

(white or blue)

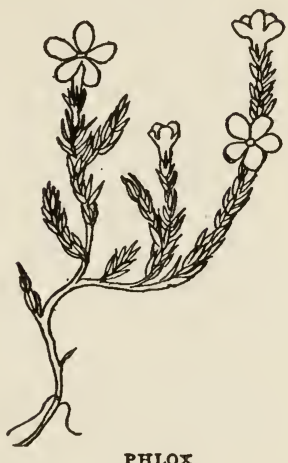

Green Gentian (Frasera). This is one of the most curious and interesting plants in the Park. It occurs freely on treeless, gravelly slopes, at the higher elevations, being one of the most conspicuous objects on the drive over Dunraven Pass. The stem is unbranched, very stout and thick, about three feet high, resembling in general outline a mullein stalk. The leaves are large and broadly lance-shaped, covering the entire stem, and the whole plant is smooth and a very pale green. The flowers, borne among the leaves, on short, slender stems, have four pointed petals; they also are green, mottled with darker spots. They are in bloom during July and early August.

Phlox (Phlox). This flower is found throughout the Park, on dry, stony slopes in the open. It can stand extreme conditions, and occurs freely on the rock slides above timberline on the mountains. The most frequent form of the plant is a low, cushion-like mat of short, narrow, rather stiff leaves growing on tangled slender stems. The numerous white flowers are scattered over the surface of the mat. The lower part of the flower is united into a narrow tube, opening at the top into five flat, round petals. 


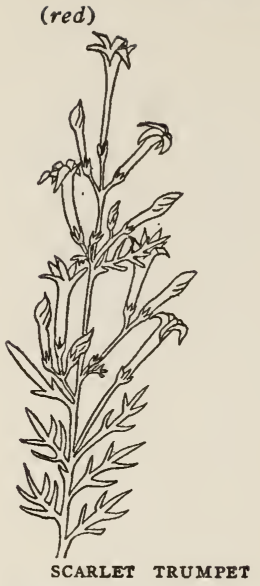

(blue)

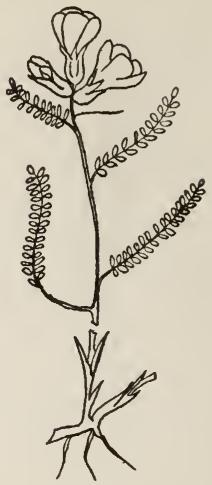

JACOB'S LADDER

Scarlet Trumpet (Gilia). This plant has a limited distribution in the Park, growing only in the southern part, in the upper Snake River valley. It is confined to dry, gravelly, sagebrush-covered soil. The rather freely branching stem is usually about two feet high. The leaves are finely divided, like carrot leaves, and have a pungent, spicy odor. The flowers, borne in threes and fours along the upper part of the stem, are long and very narrow scarlet trumpets, dividing at the end into five flaring points. They are in bloom during July and the first few days of August.

Jacob's Ladder (Polemonium). The Jacob's ladder occurs widely scattered through the Park, in moist, partly shaded places. The stems are slender and rather weak, bending or partly sprawling. The leaves are compound, with from seventeen to twenty-one small, lance-shaped leaflets along the central stalk. The flowers are grown in clusters at the ends of slender flower-stalks; they are somewhat cup-shaped, with five petals, and are of a delicate light blue. Blossoming is over early in the season at the lower levels, but persists well into July at higher elevations. 


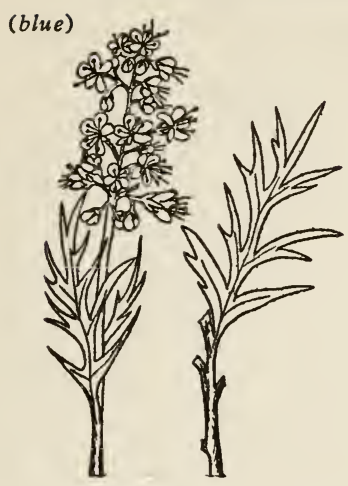

WATERLEAF

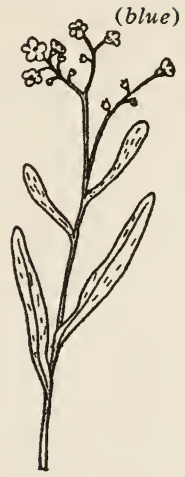

FORGET-ME-NOT

Waterleaf (Phacelia). The waterleaf is plentiful on gravelly soils; in places it forms thick bunches in the dry ditches along the roads. It is a stiffly erect plant, a foot or so in height. The stem is clothed almost to the top with leaves; these are finely cleft and divided, and both stem and leaves are somewhat hairy. The dark blue flowers are clustered in a dense spike at the summit of the stem. They are somewhat trumpetshaped, with five rounded lobes representing the petals. The stamens are long and projecting, giving the whole spike a bristly or fuzzy appearance. The blossoming season lasts from June well into July.

Forget-Me-Not (Myosotis). The true forget-menot is abundant through about the same range as that occupied by the waterleaf. It is a low plant, averaging about eight inches high, softly hairy, with narrow, pointed leaves and a loose, branching cluster of small, blue flowers. There are several other blue-flowered plants in the Park closely related to the forget-me-not; the Stickseed (Lappula), taller and coarser, whose seeds become bothersome little burrs; the Alpine Forget-Me-Not(Mertensia alpina), a small plant whose flowers are densely crowded, and the Dwarf Forget-MeNot (Eritrichium), only about two inches high. 
(blue or pink)

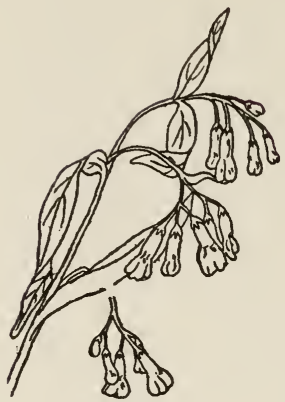

LUNGWORT (blue, red or white)

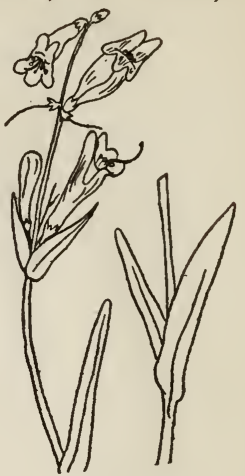

BEARDTONGUB

Lungwort (Mertensia). This flower, which is also known by the less common but prettier name, "chiming bells," is frequent throughout the Park in moist, semi-shaded places. The stems are smooth and juicy, and usually somewhat drooping, with smooth, broad lance-shaped leaves; there is also a group of leaves at the base. The flowers hang downward in clusters from long, very slender stalks; they are about half an inch in length, trumpet-shaped, with the five lobes pointing forward, forming a bell-shaped mouth. The buds are pink, as are also the flowers growing in the sun; in the usual shaded locations the full-blown flowers are blue.

Beardtongue (Pentstemon). There are several kinds of beardtongue in the Park, differing mainly in size and the number of flowers. They grow in all kinds of places, both moist and dry, open and shaded. The stems are of varying height, but the leaves are always sharply lance-shaped and oppositely arranged. There are numerous flowers arranged in a spike. The base is broadly tubular or trumpet-shaped. Two of the five round lobes at the end project upward and three downward, giving the whole a two-lipped appearance. 


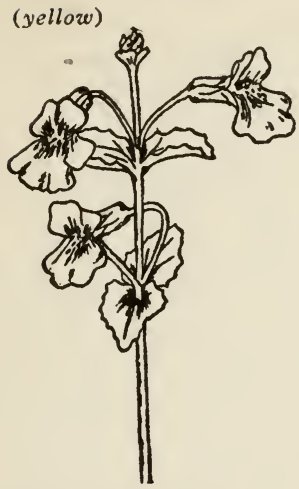

FALSE SNAPDRAGON

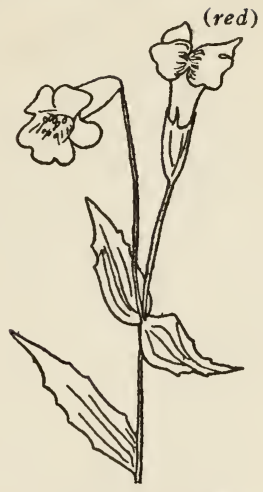

MON KEY-FLOWER

False Snapdragon (Mimulus). Properly speaking, this plant should be classed as a monkey-flower, with the species next described. It grows in wet places, usually in the open. A favorite and very peculiar location is along the run-off streams from the geysers and hot springs, the plant standing with its very roots in the warm water. The stem grows to a height of about a foot, bearing pairs of smooth, broad, sharply toothed leaves. The flowers are about an inch long, tubular at the base, cleft into a flaring, two-lipped face at the end. They are yellow in color, and bloom from June until August.

Monkey-Flower (Mimulus). There are several species of monkey-flower, of which this red one is the most striking and conspicuous. It likes moist places, and is very frequent in roadside ditches and along the banks of streams. It averages about eighteen inches in height, and its leaves are narrower and more pointed than those of the preceding species, but have fewer teeth. The whole plant is slightly hairy and somewhat sticky. The flowers are of about the same shape as those of the false snapdragon, but two or three times as large, and deep rose-red in color. The flowering season is about the same. 


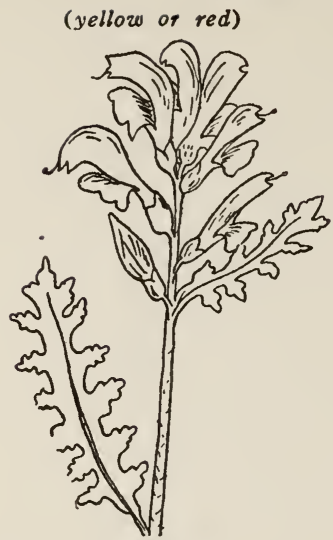

LOUSEWORT

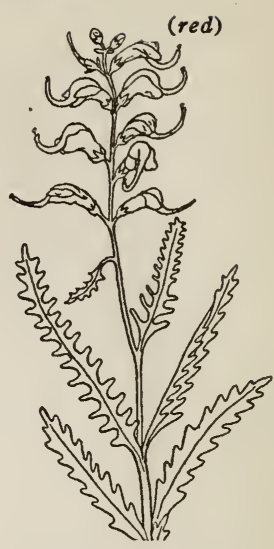

LITTLB ELEPHANT

Lousewort (Pedicularis). This plant occurs on dry, gravelly soils in grassy, open places, especially at the higher elevations. There is a stiff, rather stout upright stem, from eight to twelve inches tall, that ris. es from a rosette of leaves. Both the basal leaves and those on the stem are compound, with the leaflets deeply toothed. The yellow flowers in the spike are irregular; the upper lip long and arching, with the edges rolled inward, the lower lip shorter and curved downward. Another form, at high elevations, has a shorter stem and more finely divided leaves; its flowers are deep red, almost brown.

Little Elephant (Elephantella). This singular and very interesting plant is found all over the park plateau, in wet, open places. Its average height is about a foot, the unbranched stem ending in a spike of purple flowers. These are the striking feature of the plant: their resemblance to tiny elephant's heads is unmistakable. The upper petal is curved over like the beast's forehead, the two upper side ones suggest the flapping ears, and a long protuberance from the center of the flower supplies the trunk. 
(red to white)

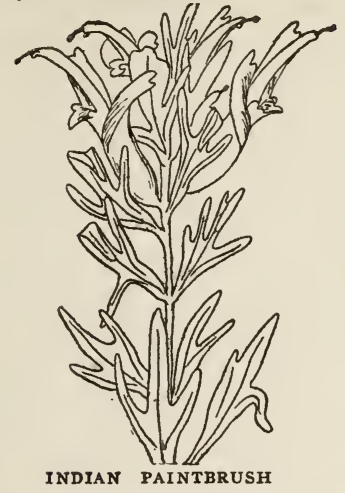

(white)

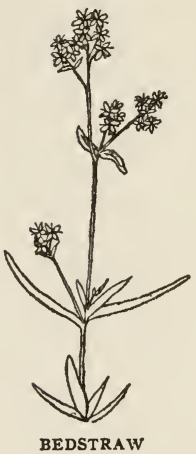

Indian Paintbrush (Castilleja).

The Indian paintbrush is one of the most conspicuous and striking of the plants in the open, usually in dry, gravelly or stony places. The plant is generally a foot or so high, with a stout, stiff, unbranched stem bearing a large number of narrow, pointed, somewhat hairy leaves, and ending in a close cluster of blossoms. The individual flowers are tubular, with deep, sharply pointed lobes at the top; they are interspersed with leaf-like structures of the same color as the flowers. The plant is recognized, however, by the mass effect of the whole group, ranging all the way from bright scarlet to rich cream-white.

Bedstraw (Galium). Bedstraw is abundant in shady, moist woods, occasionally venturing into partly open places where there is plenty of moisture. The stems are slender and smooth, averaging about two feet tall. They have four sides, and the leaves, narrow and rather blunt-ended, are arranged in groups of four. The blossoms are borne in loosely pyramidshaped groups at the ends of the branches; they are four-petaled, small, and pure white. Masses of the plant frequently make patches of misty white in the shade of the trees. 

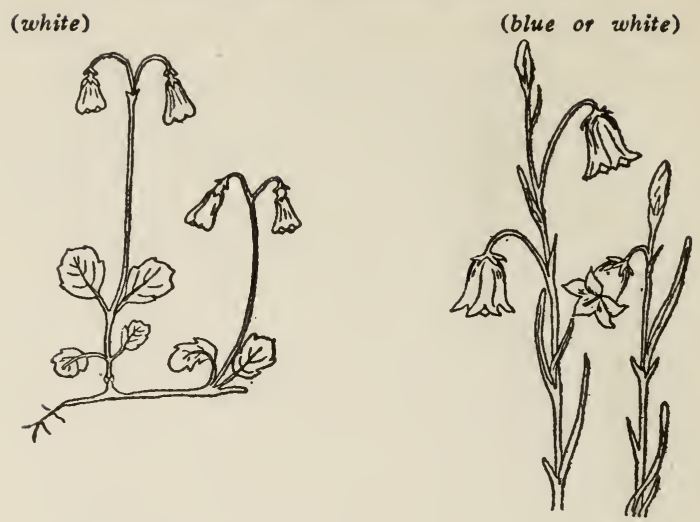

TWINFLOWER

HAREBELL

Twinflower (Linnaea). Linnaeus, the founder of modern botany, has an appropriate memorial in this little flower, one of the most delicate and beautiful plants of northern woods. In Yellowstone Park the twinflower is found only in the deepest and richest forests. The woody stem trails along the ground, bearing at intervals pairs of small, thick, round leaves, each with two obscure notches near the top. At intervals also the erect flow-stalks arise, leafless and very slender, each bearing at the summit two small, rose-white, bell-shaped, nodding flowers, with five short, rounded lobes on the margins. This flower must be sought in order to be seen, but it is worth the seeking.

Harebell (Campanula). This is another exceedingly lovely flower, and it is very abundant at the middle altitudes, preferring moist locations, either partly shaded or in the open. The stems are erect, very slender, and somewhat branching, bearing a number of exceedingly narrow, pointed leaves. At the top several nodding, bell-shaped flowers are borne; these are about an inch long, bright blue or occasionally white, with broad, blunt lobes on the margins. 


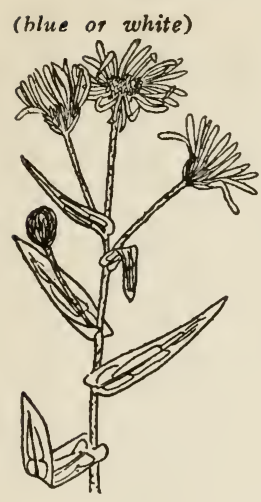

ASTER

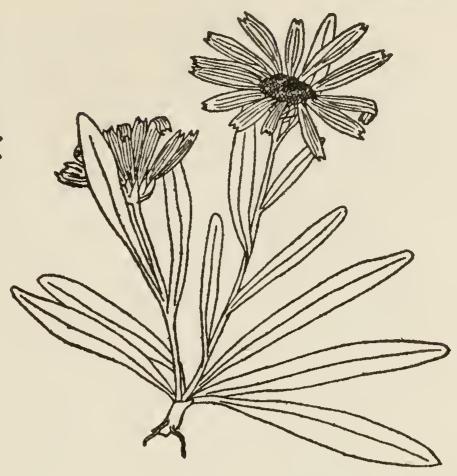

GIANT ASTER

Aster (Aster). There are so many kinds of wild aster in the Park, distinguishable only by professional botanists, that it is not worth while to describe them separately. Though the size of the flower varies greatly, ranging from one-quarter inch to over two inches in diameter, the general appearance is the same. The disk at the center is yellow, and the petals, or more properly speaking, rays, are usually blue but occasionally white. Stem and leaf habits vary greatly in the different species, and habitat preferences also; asters are found everywhere from the semi-desert hills to moist, wooded ravines. Asters are fall flowers, beginning early in July and continuing even after frost.

Giant Aster (Townsendia). This flower is not a true aster, though it strongly resembles the asters; still, its striking and peculiar appearance makes it worth separate mention. It grows in dry, exposed places, and, like many desert plants, confines its leaves to a basal rosette. The leaves are small, narrow, paddle-shaped, and rather hairy. The flower is nearly three inches in diameter, with a yellow disk about an inch across. They are borne on short, thick stems, two or three to a plant. 


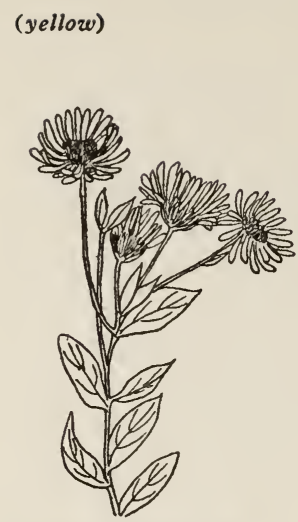

DWARF GOLDEN ASTER

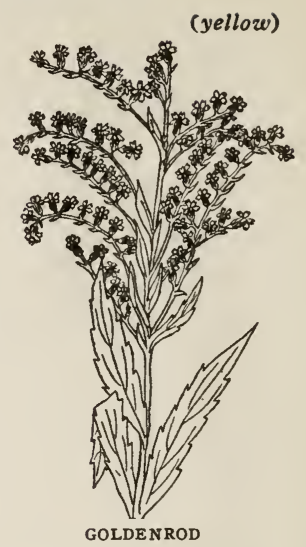

Dwarf Golden Aster (Aplopappus). This plant exists in the Park in several varieties, but like the true asters they resemble each other rather closely. They occur only in rather dry, open places, growing in considerable numbers on the hot springs formations at Mammoth. The plant is six or eight inches high, frequently with a shrubby base; small paddle-shaped leaves, usually rather rough or hairy; the blossoms resemble asters except that the petals are relatively broader and bright yellow. The blossoming season continues pretty well throughout the summer, beginning in June and lasting until late in August.

Goldenrod (Solidago). There are several kinds of goldenrod in the Park, though not so many, perhaps, as there are of the aster, for the goldenrod genus properly belongs to the plains and prairies rather than to the mountains. In most of our species the stems arise, straight and unbranching, in clumps from underground rootstocks, bearing quantities of narrow, lance-shaped, usually toothed leaves. The flowers are borne in dense, feathery clusters at the top of a rather slender stem. The blossoming season begins in July and continues at least until the frost. 


\section{(white or pink)}

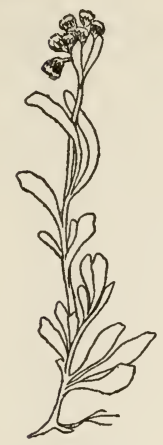

EVERLASTING

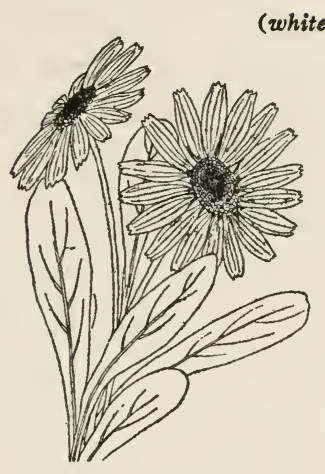

GIANT DAISY

Everlasting (Antennaria). This is a plant of the dry places, a companion of the sagebrush; it is found in arid spots at all elevations in the Park. It has a woody underground stem, from which short, tough little branches arise, forming a sprawling mat. The leaves are narrow and blunt-ended, usually hoarywhite with silky hairs. Slender flower-stalks, each bearing a few leaves, rise above the mat about eight inches; at the top the small, white, chaffy flowers are crowded into a tufted mass. The dried flowers remain on the stem, whence the common name.

Giant Daisy (Wyethia). The giant daisy is one of the most conspicuous and striking of the early flowers. It is found mainly on the park plateau, being especially abundant near the Canyon of the Yellowstone. There is an unbranched, stout hairy stem, which reaches a height of twelve to sixteen inches. The leaves are bluntly lance-shaped or somewhat oval. The striking feature is the flower. There is usually but one to a stalk, a huge, daisy-like bloom as large as a small sunflower. It reaches a diameter of about four inches, with a crown of big white or cream-colored petals, notched on the ends. It blossoms in late June and early July. 


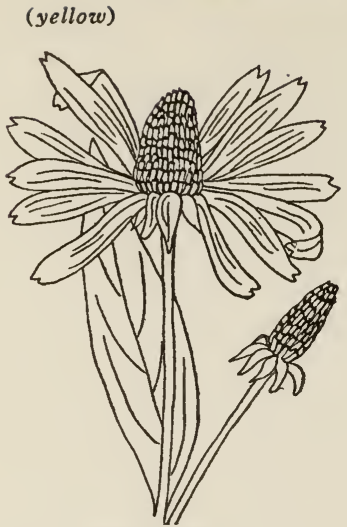

CONEFLOWER

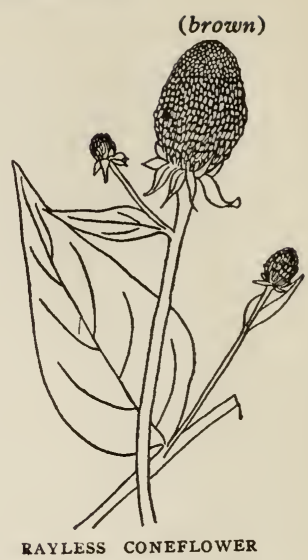

Coneflower (Rudbeckia). The yellow coneflower, or golden glow, is not abundant in the Park, but is found to a certain extent in moist, open places at the lower elevations. It is very variable in height, averaging perhaps three feet. The stem is stout and smooth, with several long branches. In addition to the stem leaves, there is usually also a considerable mass of leaves at the base; they are fairly long stemmed, broad at the outer end, and are deeply cleft into three or five divisions. The blossom resembles a small sunflower, except that its disk is elevated into a long, blunt-ended cone.

Rayless Coneflower (Rudbeckia). This plant, one of the most curious and striking in the Park, is blood. brother to the yellow coneflower, but resembles it very little in general appearance. Its height is about the same or a little less, but the stem is hairy and rough, and the leaves are broad at the base, uncleft, and come to a sharp point. They also are very rough. Of the flower there is nothing but the black, conical disk; the rays are entirely lacking. The cone is large, about an inch in diameter and one and one-half inches long. It appears in late July and lasts through August. 

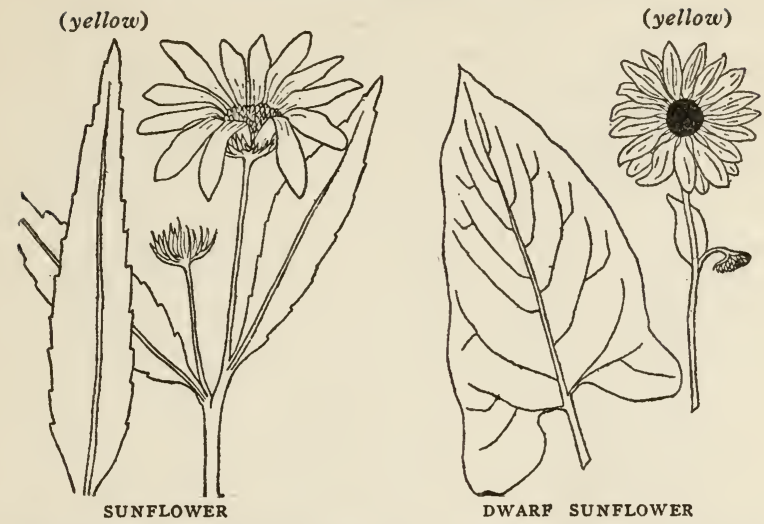

Sunflower (Helianthus). There are several sorts of wild sunflower in the Park, but they are similar in general appearance. Their stems are rather stout, ranging in height from about two to four feet, according to species. The leaves are opposite, usually lanceshaped or very narrowly oval. The flowers average between two and three inches in diameter, with broad yellow rays and either yellow or dark brown disk. The common sunflower of our backyard gardens is here in a dwarf form, usually about two feet high; it is found only at the lower elevations. The sunflowers come into bloom in July and remain until frost.

Dwarf Sunflower (Helianthella). This plant is closely related to the true sunflowers, but has several marked points of difference. Most of its leaves are in a long-stemmed basal group; they are quite large, rough, and broadly and bluntly arrow-shaped. The flower-stems are about a foot or eighteen inches tall, with a few smaller leaves. The flower-heads are borne singly; they are typical sunflowers, with yellow rays and dark disks. Range is restricted to the lower altitudes; the plant is especially abundant on the hillsides around Mammoth Hot Springs. Blossoming begins in June and ends early in July. 


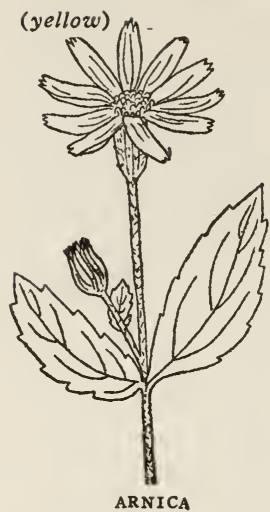

(white)

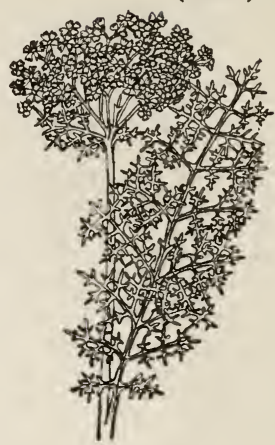

YARROW

Arnica (Arnica). This plant, whose powerful scent at once suggests its connection with the materia medi$c a$, is frequent in open places and along roadsides on the park plateau. It has an erect stem, usually unbranched, a foot or so in height; the stem and leaves as well are generally somewhat rough. The leaves are opposite, arrow-shaped, between two and three inches long, those at the base with stalks about as long as the blades. The flowers are bright yellow, sunflow. er-like heads about two inches across. Blossoming takes place during July and early August.

Yarrow (Achillea). The yarrow is one of the commonest plants in the world, being distributed throughout the northern hemisphere. It is quite abundant in the Park, even to the mountain-tops, in dry, gravelly, open locations. Its height under favorable conditions reaches fifteen to eighteen inches, though on the mountains it may be a two-inch dwarf. The stem is straight and stiff, with a few erect branches from the upper part. The leaves, both of the stem and the basal rosette, are exceedingly finely divided; whence the plant's other name, "milfoil," signifying "thousandleaf." The white flower-heads are crowded at the ends of the branches into a flat or slightly rounded mass. 


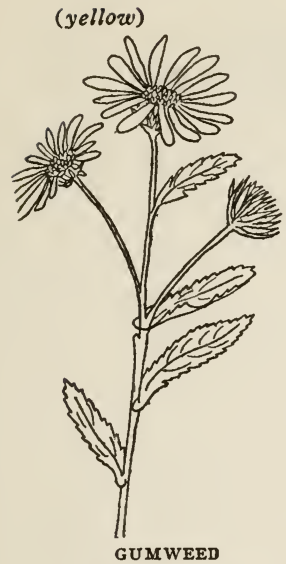

(yellow)

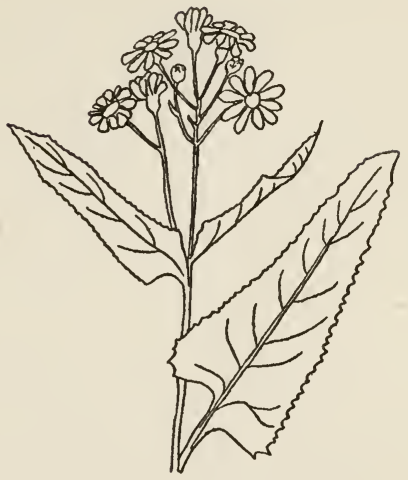

GROUNDSEL

Gumweed (Grindelia). Gumweed is a fairly common roadside plant growing in dry places at the lower and middle altitudes; it is a frequent associate of the rabbit-brush. It branches freely into a low bush, about a foot in height, the stems thickly covered, even up to the flower-heads, with many small, round, rather broad-ended leaves. All green parts are exceedingly sticky with a resinous, odorous gum. The flowers are about an inch in diameter, with many yellow rays and yellow disk; they appear in August and last until frost.

Groundsel (Senecio). This is an exceedingly abundant plant throughout the Park, in moist, open or partly sheltered places. The stems are stiff and very erect; they branch freely, and reach a height of about three feet. They are exceedingly leafy, and the leaves are long and narrowly lance-shaped, with sharply toothed margins. The blossoms are very numerous; they are small, about half an inch long and a quarter of an inch in diameter, bright yellow in color. They come into bloom in late June or early July and last until about the end of August. 


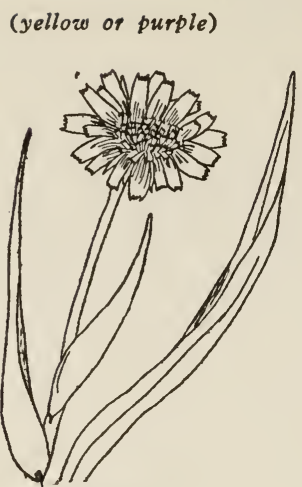

GOATSBEARD

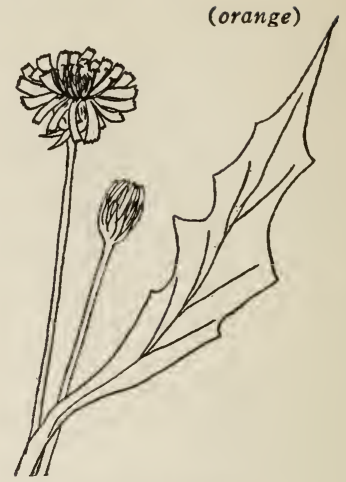

GOAT DANDELION

Goatsbeard (Tragopogon). This plant is the same as the salsify or vegetable oyster of the gardens. It is apparently an escape from cultivation, for it is found only in the neighborhood of the buildings at Mammoth Hot Springs, but it is very abundant there. The stem grows to a height of about a foot; it is somewhat leafy, and there are also leaves in a group at the base. These are shaped somewhat like broad blades of grass, thick and rather limp. Stem and leaves alike have a sort of bluish-green bloom. The flowerhead looks a good deal like an enormous dandelion. It is either yellow or purple, and is followed by a great ball of plumed seeds similar to a dandelion seed-head, but four inches or so in diameter.

Goat-Dandelion (Troximon). This is another dandelion-like plant, growing in fairly moist, open or partly-shaded places on the park plateau. The leaves are grouped into a basal rosette like that of the dandelion; they are lance-shaped, tapering off into short stalks. The flower-stalks are naked and smooth like those of the dandelion, and the yellow flowerheads also resemble dandelion blooms but are somewhat larger. There is also a second variety of the plant with smaller heads of an orange-brown color. 


\section{GAME LAWS FOR WILD FLOWERS}

Travelers from the East frequently exclaim and gasp over the abundance of flowers they find in Yellowstone Park and other mountain sanctuaries of the West-roadsides lined with forget-me-nots, whole fields of fringed gentians, mountain-sides solidly massed with lupines and wild sunflowers. The flowers seem almost miraculous, supernatural, they are so many and so beautiful.

Yet this beauty is only that of any natural, virgin territory that has never known the plow, or careless and destructive lumbering, or grazing animals other than its natural population of deer and elk. What visitors from the older parts of the country seem not to realize is that in their great-grandfathers' day the land where their cities now spread bore just such a covering of beautiful and interesting plant life as this that they now cross half a continent to see; that once on a time any random acre in the Ohio Valley, or the Atlantic States, or New England would not have suffered by comparison with any acre in the Rocky Mountains.

It was, of course, only natural and indeed inevitable that this condition should pass. A crowded population cannot live on wild-flowers; cows and plows, and even factory chimneys, are very necessary, and good in their kind. The mischief arises when men let their material desires crowd down the other things that make them men. He who is no longer willing to "sell one loaf to buy white hyacinths for his soul" is no longer quite human. Where commercial exploitation is wiping out the last remnants of the natural beauty-spots civilization has begun to back-track.

The danger of such a retrogression has become a very real one within the past few years in many of our older settled states. In one place, quarrying interests threaten the last stand of an almost extinct fern; in another, lumbermen have cut the best trees in a forest supposedly reserved for 
the State; in a third, steel mills are wiping out a whole sector of sand dunes to feed their smelters. Worst of all, however, are the depredations of misguided folk who carry home automobile loads of flowering branches, or dig up wild flowers to plant in their back yards, where the poor things generally die because of unsuitable conditions or even through sheer neglect. Indeed, a considerable commercial traffic in wild plants has grown up to satisfy this mistaken feeling, which is rapidly pushing such exquisite plants as the trailing arbutus, the moccasin flower and the fringed gentian to extinction.

To such a pass have things come in some localities, that laws have been placed on the books protecting wild flowers, just as we have laws for the protection of game birds and animals. Vermont was the leader in this movement, with a protected list of several scores of her threatened flowers and ferns, the collection is now wholly prohibited, except in very small numbers for scientific purposes. Another means for saving remnants of natural vegetation has been the establishment of wild-flower sanctuaries, which have usually taken the form of state parks, because fortunately the rarest plants usually occur in regions of unusual scenic value. In this direction the prosaic prairie state of Iowa has taken the leadership, closely followed by little, factory-crowded Connecticut. The development of state forests, as in New York and Pennsylvania, has been a great indirect help in the movement for saving some part of our wild fiowers for the pleasure and instruction of our children.

Thus in a few places at least the people have acted to keep for themselves a little of the poetic "sweetening" that makes the prosaic bread-and-butter of daily existence "go down easier" and there is good hope that the example will be followed elsewhere. It is not a thing that does itself automatically; some one is needed in each community to take the lead, but once a start is made public opinion builds itself surprisingly rapidly, and in the end the results are always worth the effort. 


\section{Index To English Names}

Alder, 20.

Alpine Forget-Me-Not, 51.

Angelica, 47.

Arnica, 62.

Aspen, 18.

Aster, 57, 58.

Barberry, 21.

Beardtongue, 52.

Bedstraw, 55.

Bee Plant, 39.

Birch, 19.

Bitter-Root, 33.

Blue-Eyed Grass, 31.

Blue Mustard, 38.

Buckbrush, 27.

Buckwheat, Wild, 33.

Burr-pod, 41.

Buttercup, 38.

Cactus, 45.

Camass, 29.

Cedar, 17.

Cherry, 24.

Chiming Bells, 52.

Choke-cherry, 24.

Cinquefoil:

Common, 40.

Shrub, 23.

Clematis, 37.

Columbine, 35.

Coneflower:

Rayless, 60.

Yellow, 60.

Coral-Root, 32.

Cottonwood:

Narrow-leaved, 18.

Trembling, 18.

Cow Parsnip, 47.

Currant, 21.

Dalsy, Giant, 59.

Dogwood, 25.

Douglas Fir, 15.

Dwarf:

Forget-Me-Not, 51.

Golden Aster, 58.

Sunflower, 61.
Elderberry, 27.

Elephant, Little, 54.

Evening Primrose, 46.

Everlasting, 59.

False:

Raspberry, 22. Snapdragon, 53. Solomon's Seal, 30.

Fir, 16.

Douglas, 15.

Fireweed, 45.

Flax, 43.

Forget-Me-Not, 51.

Fringed Gentian, 48.

Gentian:

Fringed, 48.

Green, 49.

Geranium, 42.

Giant:
Aster, 5\%.
Daisy, 59.

Globe Mallow, 43.

Goat-Dandelion, 64 .

Goatsbeard, 64 .

Golden Aster, 58.

Goldenrod, 58.

Gooseberry, 21.

Greasewood, 20.

Green Gentian, 49.

Groundsel, 63.

Gumweed, 63.

Harebell, 56.

Hollyhock, 43.

Holly-leaved Barberry, 21

Huckleberry, 26.

Indian Paintbrush, 55.

Iris, 31.

Jacob's Ladder, 50.

Juniper, 17.

Labrador Tea, 26.

Larkspur, 35.

Leather-Cup, 37.

Licorice, 41. 
Limber Pine, 14.

Little Elephant, 54.

Lodgepole Pine, 14.

Lousewort, 54.

Lungwort, 52.

Lupine, 41.

Mallow, Globe, 43.

Maple, 25.

Marigold, Marsh, 34.

Marsh Marigold, 34.

Meadowsweet, 22.

Monkey-Flower, 53.

Monkshood, 36.

Mountain Maple, 25.

Mustard, Blue, 38 .

Narrow-leaved Cottonwood, 18.

Narrow-leaved Poplar, 18.

Onion, 29.

Orchid:

Spring, 32.

Wild, 32.

Oregon Grape, 21.

Paintbrush, Indian, 55.

Parsnip, Cow, 47.

Pasque Flower, 37.

Pea, Wild, 42.

Phlox, 49.

Pine:

Limber, 14.

Lodgepole, 14.

Whitebark, 15.

Poplar:

Narrow-leaved, 18.

Trembling, 18.

Prickly Pear Cactus, 45.

Primrose, Evening, 46.

Queen's Lace, 47.

Rabbit Brush, 28.

Raspberry, False, 22.

Rayless Goldenrod, 58.

Rock Rose, 46.

Rocky Mountain Bee Plant, 39.

Rose, 24.
Sagebrush, 28.

Scarlet Trumpet, 50.

Service-Berry, 23.

Shadbush, 23.

Shooting Star, 48.

Shrub Cinquefoil, 23.

Snapdragon, 53.

Solomon's Seal, 30 .

Spiraea, 22.

Spring Orchid, 32.

Spruce, 16.

Stickleaf, 44.

Stickseed, 51.

Stonecrop, 39.

Strawberry, 40.

Sulphur Plant, 33.

Sunflower, 61.

Thimbleberry, 22.

Trembling Aspen, 18.

Twinflower, 56.

Violet:

Common, 44.

Dogtooth, 30.

Virgin's Bower, 37.

Waterleaf, 51.

Water Lily, 34.

Whitebark Pine, 15.

Willow, 19.

Wild :

Aster, 57.

Buckwheat, 33 .

Cherry, 24.

Currant, 21.

Gooseberry, 21.

Hollyhock, 43.

Onion, 29.

Orchid, 32.

Pea, 42.

Rose, 24.

Strawberry, 40.

Sunflower, 61.

Windflower, 36 .

Yarrow, 62.

Yellow Water Lily, 34. 


\section{Index To Latin Names.}

Abies, 16.

Acer, 25.

Achillea, 62.

Aconitum, 36.

Allium, 29.

Alnus, 20.

Amelanchier, 23.

Anemone, 36.

Angelica, 47.

Antennaria, 59.

Aplopappus, 58.

Aquilegia, 35.

Arnica, 62.

Artemisia, 28.

Aster, 57.

Berberis, 21.

Betula, 19.

Bossekia, 22.

Caltha, 34.

Calypso, 32.

Camassia, 29.

Campanula, 56.

Castilleja, $\mathbf{5 5 .}$

Chrysothamnus, 28.

olematis, 37.

cleome, 39.

Corallorrhiza, 32.

Cornus, 25.

Dasiophora, 23.

Delphinium, 35.

Dodecatheon, 48.

Elephantella, 54.

Epilobium, 45.
Eriogonum, 33.

Eritrichium, 51.

Erythronium, 30.

Fragaria, 40.

Frasera, 49.

Galium, 55.

Gentiana, 48.

Geranium, 42.

Gilia, 50.

Glycyrrhiza, 41.

Grindelia, 63.

Helianthella, 61.

Helianthus, 61.

Heracleum, 47.

Iris, 31.

Juniperus:

scopulorum, 17.

sibirica, 17.

Lappula, 51.

Ledum, 26.

Lewisia, 33.

Limnorchis, 32.

Linnaea, 56.

Linum, 43.

Lupinus, 41.

Mentzelia, 44.

Mertensia, 52.

Mertensia alpina, 51.

Mimulus, 53.

Myosotis, 51.

Nuphar, 34. 
Onagra, 46.

Opuntia, 45.

Pachylophus, 46.

Pedicularis, 54.

Pentstemon, 52.

Phacelia, 51.

Phlox, 49.

Picea, 16.

Pinus:

albicaulis, 15.

flexilis, 14.

murrayana, 14.

Polemonium, 50.

Populus:

angustifolius, 18.

tremuloides, 18.

Potentilla, 40.

Prunus, 24.

Pseudocymopterus, 47.

Pseudotsuga, 15.

Pulsatilla, 37.

Ranunculus, 38.
Ribes, 21.

Rosa, 24.

Rudbeckia, 60 .

Salix, 19.

Sambucus, 27.

Sarcobatus, 20.

Sedum, 39.

Senecio, 63.

Sisyrinchium, 31.

Smilacina, 30.

Solidago, 58.

Sphaeralcea, 43.

Spiraea, 22.

Symphoricarpos, 27.

Thelypodium, 38.

Townsendia, 57.

Tragopogon, 64.

Troximon, 64.

Vaccinium, 26.

Vicia, 42.

Viola, 44.

Wyethia, 59. 


487 
